\title{
Does Investor-State Dispute Settlement Discriminate Against Nationals?
}

\author{
Christian Riffel ${ }^{*}$ (D)
}

(Received 19 January 2019; accepted 9 April 2019)

\begin{abstract}
This Article answers the question of whether investor-state dispute settlement ("ISDS") discriminates against nationals by providing foreign investors with an extra avenue to challenge state measures. The complaint that ISDS is discriminatory as a matter of principle has surfaced before several European constitutional courts-including the German Federal Constitutional Court and the European Court of Justice-in connection with the ratification of the Comprehensive Economic and Trade Agreement between Canada and the European Union ("CETA"). This Article rejects this complaint. The Federal Constitutional Court was able to leave the question of discrimination open in the applications for a preliminary injunction to stop ratification. It will have to take a stand, however, in the principal proceedings. If the Court were to side with the applicants, it would sound the death knell not only for the CETA in its present form, but also for the multilateral investment court system promoted by the European Union and, in particular, Germany. The point made by the applicants in the CETA complaint is not only of importance in a European constitutional law context. Whether ISDS is per se discriminatory is a fundamental issue which requires answering before any reform steps in relation to ISDS are addressed.
\end{abstract}

Keywords: CETA complaints; investor-state dispute settlement; equality before the law; compatibility with the Basic Law; non-discrimination

\section{A. Introduction}

Investor-state dispute settlement ("ISDS")—be it institutionalized in the guise of an investment court or ad hoc-is hugely contested worldwide because of its one-dimensional focus on foreign investors. ${ }^{1}$ In Germany, the Magistrates Association posits that " $[t]$ he creation of special courts for certain groups of litigants is the wrong way forward." ${ }^{2}$ To opponents of ISDS, the whole issue comes down to this: Do foreigners need special remedies? Suffice to say they do not believe so, especially as between Western-type democracies. It is true that ISDS is merely one answer

${ }^{*}$ Dr. Riffel is a senior lecturer at the University of Canterbury in New Zealand and Associate Editor of the New Zealand Yearbook of International Law. An earlier version of this paper was presented at the Society of International Economic Law Biennial Conference Washington D.C., American University Washington College of Law, July 12-14, 2018. Many thanks to the conference participants for their valuable feedback, in particular to Steffen Hindelang and Martin Björklund.

${ }^{1}$ See e e.g., Rhea Tamara Hoffmann, Divergenz Und Transformation: Verfassungstheoretische UnTERsuchung DES EIgENTUMSSCHUTZES IN DER DEMOKRATISHEN EIgENTUMSVERFASSUNG UND IM INVESTITIONSSCHUTZREGIME 416-18 (2019); Ernst-Ulrich Petersmann, EU Constitutional Law as Restraint for EU Trade and Investment Agreements: The Example of CETA and Investor-State Dispute Settlement, 2 EUR. INV. L. \& ARB. REV. 318, 323, 327-28, 332 (2017).

${ }^{2}$ Deutscher Richterbund, Stellungnahme zur Errichtung eines Investitionsgerichts für TTIP - Vorschlag der Europäischen Kommission vom 16.09.2015 und 12.11.2015 (No. 4/16, Feb. 2016), https://www.foeeurope.org/sites/default/files/eu-us_ trade_deal/2016/english_version_deutsche_richterbund_opinion_ics_feb2016.pdf. 
to the controversy over the proper forum for the settlement of investment disputes. The examples of South Africa and Brazil show that there are other ways to enforce investors' rights. Foreign investors in South Africa are compelled to rely on mediation and the national system, ${ }^{3}$ while Brazil has adopted an ombudsman model. ${ }^{4}$ Many academic experts even propose that "[a]ll private stakeholders (not just foreign investors) should have access to effective surveillance mechanisms regarding the compliance of the signatories with their obligations under these international trade agreements (including obligations on sustainability, environmental, social and health protection)." 5

The present Article seeks to answer the question of whether ISDS discriminates against national investors. This issue has vexed several national constitutional courts-including the German Federal Constitutional Court and the Court of Justice of the European Union ("ECJ")in the context of the ratification of the Comprehensive Economic and Trade Agreement between Canada and the European Union ("CETA"). ${ }^{6}$ The parts of the CETA that come under the exclusive competence of the European Union have been provisionally applied since September 21, 2017, following the consent of the European Parliament. ${ }^{7}$ The provisional application excepts the investor-state dispute resolution mechanism established in Section F of Chapter 8 of the CETA. ${ }^{8}$ The complaints are predicated on the fact that the CETA allows foreign investors to take legal action against the host state but does not provide the same option to host country investors. Only foreigners have legal standing, whereas nationals-those having invested only domestically-are precluded from challenging measures of their own government before the CETA Tribunal. ${ }^{9}$

Whether this amounts to discrimination is disputed. The complainants' argument is reminiscent of the Calvo doctrine-denying foreign investors any special property enforcement rights outside of the national legal order. ${ }^{10}$ While some commentators assume discrimination, ${ }^{11}$ the French Constitutional Council and the ECJ took the opposite view. ${ }^{12}$ For Lowe, investment protection is discriminatory per se whenever it goes beyond national treatment. ${ }^{13}$ In any event, it is not an issue for international law-which is neutral on this point-but first and foremost

\footnotetext{
${ }^{3}$ Protection of Investment Act 22 of $2015 \$ 13$ (S. Afr.), https://www.gov.za/documents/protection-investment-act-222015-15-dec-2015-0000.

${ }^{4}$ Brazil Model BIT 2015 (Cooperation and Facilitation Investment Agreement) arts. 18, 23(1), https://investmentpolicy. unctad.org/international-investment-agreements/treaty-files/4786/download.

5"Trading Together" Declaration of 25 Jan. 2017, https://www.trading-together-declaration.org/.

${ }^{6}$ Comprehensive Economic and Trade Agreement Between Canada, of the one part, and the European Union and its Member States, of the other part, Oct. 30, 2016 [hereinafter CETA]. For the complaint before the Federal Constitutional Court, see VERFASSUNGSBESCHWERDE, https://www.ceta-verfassungsbeschwerde.de/. For the request for an opinion of the ECJ submitted by the Kingdom of Belgium pursuant to Article 218(11) of the Treaty on the Functioning of the European Union, see ECJ, Opinion 1/17, ECLI:EU:C:2019:341, Opinion of 30 Apr. 2019, http://curia.europa.eu/juris/ recherche.jsf?language $=$ en [hereinafter CETA Opinion].

${ }^{7}$ Council Decision (EU) 2017/38, on the provisional application of the Comprehensive Economic and Trade Agreement (CETA) between Canada, of the one part, and the European Union and its Member States, of the other part, 2017 O.J. (L11) 1.

${ }^{8}$ Id. at art. $1(1)(\mathrm{a})$.

${ }^{9}$ CETA art. 8.18.1.

${ }^{10} C f$. G.A. Res. 3281 (XXIX), Charter of Economic Rights and Duties of States (Dec. 12, 1974) art. 2(2)(a), second sentence ("No State shall be compelled to grant preferential treatment to foreign investment."). For the Calvo doctrine, see JESWALD W. Salacuse, The Law of Investment Treaties 75-78 (2nd ed. 2015).

${ }^{11}$ Taylor St John, The Rise of Investor-State Arbitration: Politics, LaW, and Unintended Consequences 253-54 (2018); Marco Bronckers, Is Investor-State Dispute Settlement (ISDS) Superior to Litigation Before Domestic Courts? An EU View on Bilateral Trade Agreements, 18 J. INT'L ECON. L. 655, 672-74, 677 (2015).

${ }^{12}$ Conseil constitutionnel [CC] [Constitutional Court], decision No. 2017-749 DC, July 31, 2017, https://www.conseilconstitutionnel.fr/decision/2017/2017749DC.htm [hereinafter Constitutional Council decision on CETA]; CETA Opinion, supra note 6 , at para. 180 .

${ }^{13}$ Vaughan Lowe, Changing Dimensions of International Investment, IN COLLECTED COURSES 2006, vOL. 1, 431-32 (Xiamen Academy of International Law ed., 2008).
} 
a national law problem. ${ }^{14}$ If the protection under international law leads to discrimination in the domestic legal order, then it is for domestic law to remedy this situation, for example, by increasing the level of protection afforded to nationals. The German Federal Court of Justice confirmed that the discrimination of nationals is due to national law, and therefore the alleged discrimination is to be assessed in light of national norms. ${ }^{15}$

Even worse, from the vantage point of national investors, the CETA expressly negates direct effect, which signifies that the CETA cannot "be directly invoked in the domestic legal systems of the Parties." ${ }^{16}$ Moreover, pursuant to the second paragraph of Article 30.6 of the CETA, "[a] Party shall not provide for a right of action under its domestic law against the other Party on the ground that a measure of the other Party is inconsistent with this Agreement." ${ }^{\prime 7}$ Consequently, nationals are barred from bringing a case against the other Party before a domestic court and against their own government before the CETA Tribunal. ${ }^{18}$ It should be stressed, however, that the problem here is that national investors are unable to have a measure of their own government reviewed, not "a measure of the other Party," by an international forum.

The cases are argued, in part, on the basis of the principle of equality before the law. Is ISDS, which was designed to promote the international rule of law, ${ }^{19}$ at odds with the principle of equality before the law, which itself forms part of the rule of law? ${ }^{20}$ The principle of equality before the law entails that like cases are treated equally in terms of substance as well as procedure. From this principle, the requirement of equal procedural rights ensues. The Federal Constitutional Court could leave the question of discrimination open in the applications for a preliminary injunction but will have to take a stand in the principal proceedings. ${ }^{21}$ The point made in the CETA complaints is not only of importance to a European constitutional law context. Whether investor-state adjudication is discriminatory by default is a fundamental issue which requires answering before any reform steps relating to ISDS are addressed. ${ }^{22}$

The issue is related to the more general question of whether preferential treatment of foreigners discriminates against nationals. In this regard, the U.S.-Mexico General Claims Commission in Hopkins v. Mexico held as early as 1926:

[I]t not infrequently happens that under the rules of international law applied to controversies of an international aspect a nation is required to accord to aliens broader and more liberal treatment than it accords to its own citizens under its municipal laws.... There is no ground to object that this amounts to a discrimination by a nation against its own citizens

\footnotetext{
${ }^{14} \mathrm{Cf}$. Bundesgerichtshof [BGH] [Federal Court of Justice], Sept. 18, 1989, Neue Juristische Wochenschrift [NJW] 1990, 108 (Ger.); Ursula Rust, Artikel 18 AEUV, in EUROPÄISCHES UnIONSRECHT, VOL. 1, para. 10 (Hans von der Groeben, Jürgen Schwarze \& Armin Hatje eds., 7th ed. 2015).

${ }^{15}$ Bundesgerichtshof [BGH] [Federal Court of Justice], Case No. IX AR (VZ) 1/12, para. 31, (Sept. 19, 2013), http://www. bundesgerichtshof.de/DE/Entscheidungen/entscheidungen_node.html.

${ }^{16}$ CETA art. 30.6.1.

${ }^{17} I d$. art. 30.6.2.

${ }^{18}$ See also id. art. 8.18.1 ("[A]n investor of a Party may submit to the Tribunal ... a claim that the other Party has breached an obligation ....”) (emphasis added).

${ }^{19}$ Aron Broches, Selected Essays: World Bank, ICSID, and Other Subjects of Public and Private International LAW 163 (1995); Peter H. Chase, TTIP, Investor-State Dispute Settlement and the Rule of Law, 14 EUR. VIEW 217, 218 (2015).

${ }^{20}$ For a definition of "rule of law," see BLACK's LAW DiCTIONARY (10th ed. 2014).

${ }^{21}$ Bundesverfassungsgericht [BVerfG] [Federal Constitutional Court], 2 BvR 1368/16, paras. 36-37 (Oct. 13, 2016), https:// www.bundesverfassungsgericht.de/DE/Entscheidungen/Suche/suche_node.html.

${ }^{22}$ For the reform options, see Anthea Roberts, UNCITRAL and ISDS Reform: Pluralism and the Plurilateral Investment Court, EJIL: Talk! (Dec. 12, 2017), https://www.ejiltalk.org/uncitral-and-isds-reform-pluralism-and-the-plurilateralinvestment-court/. For the German proposal for bilateral investment courts, see Markus Krajewski, ModellInvestitionsschutzvertrag mit Investor-Staat-Schiedsverfahren für Industriestaaten unter Berücksichtigung der USA, FEDERAL Ministry FOR ECONOMIC AfFAIRS AND ENERGY (May 4, 2015), https://www.bmwi.de/Redaktion/DE/Downloads/M-O/ modell-investitionsschutzvertrag-mit-investor-staat-schiedsverfahren-gutachten.pdf.
} 
in favor of aliens. It is not a question of discrimination, but a question of difference in their respective rights and remedies. The citizens of a nation may enjoy many rights which are withheld from aliens, and, conversely, under international law aliens may enjoy rights and remedies which the nation does not accord to its own citizens. ${ }^{23}$

This ruling of the General Claims Commission is, of course, not binding upon national constitutional courts. Among other things, the standards of review differ. Whereas the objective of international investment law is to protect foreigners, not nationals, ${ }^{24}$ the issue in a constitutional complaint is compliance with the national constitution.

Equality before the law is a constitutional requirement enshrined in many jurisdictions. ${ }^{25}$ Article 14(1) of the International Covenant on Civil and Political Rights ("ICCPR"), for example, provides that "[a]ll persons shall be equal before the courts and tribunals." ${ }^{26}$ According to the International Court of Justice, "[ $t$ ] he principle of equality of the parties follows from the requirements of good administration of justice." ${ }^{27}$ European courts are not unfamiliar with the phenomenon of reverse discrimination, as it can be caused by European Union law itself, which, as a rule, does not capture purely internal situations: ${ }^{28} \mathrm{EU}$ foreigners are to be treated more favorably than nationals in the like situation by an EU Member State because, as the case may be, a national rule does not apply to EU foreigners by virtue of the primacy of European Union law. ${ }^{29}$

The national legal orders of EU Member States have responded differently to this phenomenon. In Austria, for instance, the European Convention on Human Rights ("ECHR") has constitutional status. ${ }^{30}$ The discrimination of nationals is thus reviewed in light of the prohibition of discrimination in Article 14 of the ECHR. ${ }^{31}$ Therefore, if no objective ground of justification can be found, the discrimination will be deemed unconstitutional. ${ }^{32}$ In Germany, reverse discrimination is measured against Article 3(1) of the Basic Law, which ensures equality before the law within the German legal order. ${ }^{33}$ It is contested, however, if Article 3(1) of the Basic Law finds application in constellations when the complaint aims at the removal of unlawful preferential treatment of

\footnotetext{
${ }^{23}$ George W. Hopkins (U.S.A.) v. United Mexican States, 4 REP. INT'L ARbitral AwARDS 41, para. 16 (1926), http://legal.un. org/riaa/cases/vol_IV/41-47.pdf (emphasis added).

${ }^{24}$ Chios Carmody, Recalibrating the Embedded Liberalism Compromise: "Legitimate Expectations" and International Economic Law, in The Future of International Economic InTEgration: The Embedded Liberalism Compromise Revisited 72 (Gillian Moon \& Lisa Toohey eds., 2018). Cf. preamble to CETA rec. 8 ("Recognising that the provisions of this Agreement protect investments and investors with respect to their investments ...").

${ }^{25}$ See GA Res. 217 A (III), Universal Declaration of Human Rights arts. 7, 10 (Dec. 10, 1948); Charter of Fundamental Rights of the European Union art. 20, Dec. 7, 2000, (2001) 2000 O. J. (C 364) [hereinafter Charter of Fundamental Rights].

${ }^{26}$ International Covenant on Civil and Political Rights, Dec. 16, 1966, 999 U.N.T.S. 171 [hereinafter ICCPR].

${ }^{27}$ Judgments of the Administrative Tribunal of the I.L.O. upon complaints made against the U.N.E.S.C.O., Advisory Opinion, 1956 I.C.J. 77, 86 (Oct. 23).

${ }^{28}$ Joined Cases C-64/96 \& C-65/96, Uecker and Jacquet, 1997 E.C.R. I-3171, paras. 16, 23; DAmian Chalmers, GARETH Davies \& Giorgio Monti, European Union LaW 494 (3rd ed. 2014).

${ }^{29}$ Hans D. Jarass, Art. 3, in GrundGesetz FÜr DIE BundeSREPUblik DeUtschland: Kommentar, para. 97 (Hans D. Jarass \& Bodo Pieroth eds., 15th ed. 2018); Jost Pietzcker, $\$ 125$ Der allgemeine Gleichheitssatz, in HANDBUCH DER GRUNDRECHTE IN Deutschland und Europa, vol. V: Grundrechte in Deutschland - Einzelgrundrechte II, para. 97 (Detlef Merten \& Hans-Jürgen Papier eds., 2013); Astrid Epiney, Art. 18 AEUV, in EUV/AEUV: DAS VerfassungsreCHT DER EUROPÄISCHEN Union mit EURopäISCHER GRUndrechtecharta, para. 27 (Christian Callies \& Matthias Ruffert eds., 5th ed. 2016); Rainer Bösch, Die Inländerdiskriminierung, 31 JURA 91, 91 (2009).

${ }^{30}$ Convention for the Protection of Human Rights and Fundamental Freedoms, Nov. 4, 1950, 213 U.N.T.S. 222 [hereinafter ECHR]. See Permanent Representation of Austria to the Council of Europe, European Court of Human Rights (2019), https:// www.bmeia.gv.at/en/oev-strasbourg/council-of-europe/european-court-of-human-rights/.

${ }^{31}$ Verfassungsgerichtshof [VfGH] [Constitutional Court], June 17, 1997, B592/96 (Austria), https://www.ris.bka.gv.at/ $\mathrm{Vfgh} /$.

${ }^{32}$ Verfassungsgerichtshof [VfGH] [Constitutional Court], Mar. 1, 2004, G110/03 ua, 8 (Austria); Verfassungsgerichtshof [VfGH] [Constitutional Court], Dec. 15, 2004, G79/04 ua, 7 (Austria).

${ }^{33}$ Case No. IX AR (VZ) 1/12, supra note 15 , at para. 31.
} 
third parties, such as the elimination of distortions of competition. ${ }^{34}$ In one minority view, Article 3(1) of the Basic Law does not capture reverse discrimination: Each legislature is only held accountable for their respective areas of responsibility-something that is generally acceptedeven though Germany, through its participation in the Council, was involved in the making of the European law causing the discrimination of nationals, just as it would be in the case of CETA through its ratification. ${ }^{35}$

In the present instance, the discrimination of nationals would result from an international instrument. If successful, the complaints would sound the death knell not only for the CETA in its present form, but also for the project of the European Union to negotiate a multilateral investment court. ${ }^{36}$

\section{B. Implications of a Veto by the Federal Constitutional Court}

\section{Impugnability of the Ratification Act}

In the German CETA complaint, the Federal Constitutional Court has been called to review the legality of the German ratification act in light of the German constitution, the Basic Law. ${ }^{37}$ A preliminary question is why the ratification act should be impugnable. The starting point is that ratification is subject to national constitutional law. Article 1.1 CETA defines the Member States as "Parties." 38 As a mixed agreement, the CETA can only fully enter into force once the European Union and all EU Member States have ratified it. ${ }^{39}$ Since Opinion 2/15, it is clear that ISDS falls within the purview of the EU Member States. ${ }^{40}$

Commensurate with the Bosphorus doctrine of the European Court of Human Rights, the German state would be foreclosed from selling out constitutional rights protection by joining an international legal regime. ${ }^{41}$ This is borne out by the eternity clause in Article 79(3) of the Basic Law, which stipulates that "[a]mendments to this Basic Law affecting ... the principles laid down in Articles 1 and 20 shall be inadmissible." Articles 1 and 20 cover the basic rights-including the principle of equal treatment-and constitutional precepts such as the rule of law and due process. The exercise of external power by the government is thus limited by the basic rights. ${ }^{42}$ As a result, when it comes to passing ratification in Germany, the Federal Constitutional Court is the gatekeeper.

Considering Article 27 of the Vienna Convention on the Law of Treaties ("VCLT"), ${ }^{43}$ the accession already would have to be stopped to avoid a potential conflict of norms. For, externally, Germany would be bound by the CETA after its entry into force, even if the CETA was incompatible with the Basic Law. This legal effect is reinforced by Article 216(2) of the Treaty on the

\footnotetext{
${ }^{34}$ Pietzcker, supra note 29 , at para. 87.

${ }^{35} I d$. at paras. $99-100$.

${ }^{36}$ For the negotiating directives, see European Council, Multilateral Investment Court: Council Gives Mandate to the Commission to Open Negotiations (Mar. 20, 2018), http://www.consilium.europa.eu/en/press/press-releases/2018/03/20/ multilateral-investment-court-council-gives-mandate-to-the-commission-to-open-negotiations/.

${ }^{37}$ GRUNDGESETZ [GG] [BASIC LAW] art. 93(1)(4a) in conjunction with Bundesverfassungsgerichtsgesetz [BVerfGG] [Act on the Federal Constitutional Court], Mar. 12, 1951, \$13(8a), available at http://www.gesetze-im-internet.de/ englisch_gg/ (BASIC LAw), http://www.bundesverfassungsgericht.de/SharedDocs/Downloads/EN/Gesetze/BVerfGG.pdf?_blob= publicationFile\&v=1 (Act on the Federal Constitutional Court).

${ }^{38}$ See also Guillaume Van der Loo \& Ramses Wessel, The Non-ratification of Mixed Agreements: Legal Consequences and Solutions, 54 Common MKT. L. Rev. 735, 742-43, 746 (2017).

${ }^{39} \mathrm{CETA}$ art. 30.7.2.

${ }^{40}$ ECJ, Opinion 2/15, ECLI:EU:C:2017:376, Opinion of 16 May 2017, paras. 292-93.

${ }^{41}$ Bosphorus Hava Yolları Turizm ve Ticaret Anonim Şirketi v. Ireland, App. No. 45036/98, para. 154 (June 30, 2005), http://hudoc.echr.coe.int/eng?i=001-69564.

${ }^{42}$ BASIC LAW art. 1(3).

${ }^{43}$ Vienna Convention on the Law of Treaties, May 23, 1969, 1155 U.N.T.S. 331 [hereinafter VCLT].
} 
Functioning of the European Union ("TFEU"), ${ }^{44}$ pursuant to which "[a]greements concluded by the Union are binding ... on its Member States," making compliance with the CETA an obligation arising from European Union law as well. For that reason, it is in the legal interest of the applicants to have the ratification act declared incompatible with the Basic Law. ${ }^{45}$

\section{Incompatibility with the Basic Law}

Should the Federal Constitutional Court disallow accession to CETA, the fallout of such a finding would also have implications for other German international investment agreements, including an envisaged convention for the establishment of a multilateral investment court. On principle, equality before the law does not prescribe a particular outcome but is relative ${ }^{46}$ - for it is the prerogative of the legislature to decide how to correct a found discrimination. ${ }^{47}$ Theoretically, an existing discrimination can be corrected in two ways-by treating the formerly favored group worse or by treating the formerly discriminated-against group better. ${ }^{48}$ According to the ECJ, only the latter applies with regard to double taxation conventions. ${ }^{49}$ The arbitral tribunal in Achmea $v$. Slovakia (I) opined that "the answer is to extend rights and not to cancel them." 50 At this juncture, it should be noted that the Federal Constitutional Court would not be in a position to grant the applicants access to the CETA Tribunal. This would require altering the legal text of the CETA, and hence require the consent of Canada, the European Union, and the other EU Member States. If every investor - foreign and national-was given access to an investment court, this would change the whole nature of investment arbitration. If nationals could take legal action against their own government, the ISDS system would be turned into a forum to protect proprietary rights in general, not unlike a human rights court but confined to property. In this connection, it is worth calling to mind the primary purpose of international investment law: to facilitate the flow of foreign capital. ${ }^{51}$ The only unilateral solution would be, therefore, to withdraw from existing agreements with an ISDS clause and not to join new ones- to the detriment of German overseas investors. ${ }^{52}$

The irony, of course, is that not only did Germany conclude the first bilateral investment treaty ("BIT") with Pakistan in 1959, ${ }^{53}$ but no other country has concluded more BITs. ${ }^{54}$ The Basic Law was not seen as a hindrance then, nor when the Convention on the Settlement of Investment Disputes between States and Nationals of Other States ("ICSID Convention") ${ }^{55}$ was ratified by Germany in $1969 .{ }^{56}$

\footnotetext{
${ }^{44}$ Treaty on the Functioning of the European Union, Dec. 13, 2007, 2008 O.J. (C 115) 47 [hereinafter TFEU].

${ }^{45}$ Act on the Federal Constitutional Court $\$ \$ 31(2), 95(3)$.

${ }^{46}$ Pietzcker, supra note 29, at paras. 10, 31, 111; Jarass, supra note 29, at para. 32.

${ }^{47}$ Pietzcker, supra note 29 , at para. 113.

${ }^{48} I d$. at para. 111; Jarass, supra note 29 , at para. 32.

${ }^{49}$ Case C-376/03, D. v. Inspecteur van de Belastingdienst/Particulieren/Ondernemingen buitenland te Heerlen, 2005 E.C.R. I-5821, para. 56.

${ }^{50}$ Achmea B.V. (formerly Eureko B.V.) v. Slovk. (I), PCA Case No. 2008-13, Award on Jurisdiction, Arbitrability and Suspension, para. 274 (Oct. 26, 2010), https://investmentpolicy.unctad.org/investment-dispute-settlement.

${ }^{51}$ See preamble to CETA rec. 8 ("Recognising that the provisions of this Agreement ... are intended to stimulate mutuallybeneficial business activity ...”). See also Rudolf Dolzer \& Christoph Schreuer, Principles of International INVESTMENT LAW 27 (2nd ed. 2012).

${ }^{52}$ Andrej Lang, Die Autonomie des Unionsrechts und die Zukunft der Investor-Staat-Streitbeilegung in Europa nach Achmea, Beiträge zum Transnationalen WirtschaftsRecht 47 (2018).

${ }^{53}$ Treaty Between the Federal Republic of Germany and Pakistan for the Promotion and Protection of Investments, Nov. 25, 1959, which did not contain an ISDS clause yet.

${ }^{54}$ See Investment Policy Hub, InTERnational InVESTMENT AgreEMENTS NAVIGATOR, https://investmentpolicy.unctad.org/ international-investment-agreements/by-economy\#iiaInnerMenu.

${ }^{55}$ Convention on the Settlement of Investment Disputes Between States and Nationals of Other States, Mar. 18, 1965, 17 U.S.T. 1290, 575 U.N.T.S. 192 [hereinafter ICSID Convention].

${ }^{56}$ See Database of ICSID Member States, InTERnAtional CEnTre FOR SETtLement of Investment Disputes (2019), https://icsid.worldbank.org/en/Pages/about/Database-of-Member-States.aspx.
} 


\section{Termination of the Provisional Application}

In principle, the ratification of a mixed agreement by an EU Member State only concerns matters of the agreement falling within Member State competences-be they exclusive or shared but not yet exercised by the Union within the meaning of Article 2(2) of the TFEU. ${ }^{57}$ This is apparent from the fact that those matters can be decoupled and put in a separate agreement, as is envisioned in the wake of Opinion 2/15 with the standalone investment protection agreements with Singapore and Vietnam. The ECJ held:

The contracting parties to a mixed agreement concluded with third countries are, first, the European Union and, second, the Member States. When such an agreement is negotiated and concluded, each of those parties must act within the framework of the competences which it has while respecting the competences of any other contracting party. ${ }^{58}$

By the same token, the rejection of a mixed agreement by an EU Member State can only affect matters which remain within the competence of the Member States. ${ }^{59}$ Yet, because of the European customs union, ${ }^{60}$ the CETA cannot be terminated unilaterally by one Member State-for example, only for the territory of the Federal Republic of Germany. ${ }^{61}$ A German rejection would therefore prompt the European Union, first, not to ratify it, and second, to terminate its provisional application pursuant to Article 30.7.3(c) of the CETA, which supersedes Article 25(2) of the VCLT. ${ }^{62}$ Accordingly, the Council stated when authorizing the signature of the CETA:

If the ratification of CETA fails permanently and definitively because of a ruling of a constitutional court, or following the completion of other constitutional processes and formal notification by the government of the concerned state, provisional application must be and will be terminated. The necessary steps will be taken in accordance with EU procedures. ${ }^{63}$

As far as the internal EU procedures are concerned, it is disputed if paragraph 5 or paragraph 9 of Article 218 of the TFEU is the proper legal basis to terminate the provisional application. ${ }^{64}$ Be that as it may, both legal bases lead to the same decision-making rule in Article 218(8) of the TFEU.

\section{Relevance of the ECJ Ruling in Achmea}

Achmea, too, was argued on the basis of Article 18(I) of the TFEU, which prohibits "any discrimination on grounds of nationality" within the remit of the European Treaties. ${ }^{65}$ That provision is binding upon EU Member States. ${ }^{66}$ One question asked in that case was if an intra-EU ISDS

\footnotetext{
${ }^{57}$ Van der Loo \& Wessel, supra note 38 , at 743,757 . The problem is, of course, that a mixed agreement does not spell out which portion of it comes within the scope of Member State competence. On this point, see id. at 752-53.

${ }^{58}$ ECJ, Case C-28/12, Comm'n v. Council, para. 47, ECLI:EU:C:2015:282, Judgment of 28 Apr. 2015 (emphasis added).

${ }^{59}$ David Kleimann \& Gesa Kübek, The Signing, Provisional Application, and Conclusion of Trade and Investment Agreements in the EU: The Case of CETA and Opinion 2/15, 45 LEGAL Issues ECON. INTEGRATION 13, 34 (2018); Joris Larik, Prêt-à-ratifier: The CETA Decision of the French Conseil constitutionnel of 31 July 2017, 13 EUR. CONST. L. REv. 759, 772 (2017).

${ }^{60}$ TFEU art. 28(1).

${ }^{61}$ Kleimann \& Kübek, supra note 59, at 29-30.

${ }^{62}$ Van der Loo \& Wessel, supra note 38, at 760-62. For ways to salvage CETA after an EU Member State has rejected it, see Kleimann \& Kübek, supra note 59, at 34-36.

${ }^{63}$ Statement from the Council, 2017 O.J. (L 11) 9, 15, point 20.

${ }^{64}$ Van der Loo \& Wessel, supra note 38, at 761-62, para. 5; Kleimann \& Kübek, supra note 59, at 30, para. 9.

${ }^{65}$ ECJ, Case C-284/16, Slovk. v. Achmea, para. 23, ECLI:EU:C:2018:158, Judgment of 6 Mar. 2018 [hereinafter Achmea]. For a case summary, see Csongor István Nagy, Intra-EU Bilateral Investment Treaties and EU Law After Achmea: "Know Well What Leads You Forward and What Holds You Back," 19 GERMAN L.J. 981, 988-96 (2018).

${ }^{66}$ Stefan Lorenzmeier, AEUV Artikel 18 (ex-Artikel 12 EGV) [Diskriminierungsverbot], in EUROPÄISCHES UNIONSRECHT: HANDKOMmentar para. 3 (Christoph Vedder \& Wolff Heintschel von Heinegg eds., 2nd ed. 2018).
} 
mechanism constitutes discrimination because it confers on investors from one Member State "the right to have recourse to international arbitration" against another Member State, "a right not enjoyed by investors from other Member States." ${ }^{27}$

\section{Adverse Effect on the Autonomy of EU Law}

The ECJ rejected intra-EU ISDS, not merely in the specific form at issue, but in general. ${ }^{68}$ This is because the argument of the Court— "adverse effect on the autonomy of EU law"—can be generalized. ${ }^{69}$ One of the critical considerations was:

[W] hether an arbitral award made by such a tribunal is, in accordance with Article 19 TEU in particular, subject to review by a court of a Member State, ensuring that the questions of EU law which the tribunal may have to address can be submitted to the Court by means of a reference for a preliminary ruling. ${ }^{70}$

This, of course, would turn the ISDS system on its head. Article 53(1) of the ICSID Convention provides that " $\mathrm{t}]$ he award shall be binding on the parties and shall not be subject to any appeal or to any other remedy except those provided for in this Convention." 71 To subject ISDS awards to review by a court of a Member State - and possibly the ECJ if questions of European Union law should arise-would thwart their finality and thus their enforceability. ${ }^{72}$ Additionally, it would also be at variance with "the neutrality and the autonomy of the resolution of investor-State disputes vis-à-vis the judicial systems of the Parties."73 Questions of European Union law will arise because an international investment agreement concluded by the European Union, such as the CETA, forms part of the EU legal order ${ }^{74}$ - making the interpretation of the agreement an interpretive act of European Union law. ${ }^{75}$ The fact remains that European Union law, including ECJ rulings, may violate the agreement, and European Union law may not be invoked as justification for failure to perform that agreement to which the European Union is a party. ${ }^{76}$ The mandate of the ISDS system is to review the lawfulness of a government measure as applied and construed by national authorities, such as domestic courts, in light of investment protection standards. ${ }^{77}$ In the present instance, the measure at issue can be a European Union act or an act of an EU Member State. Contrary to the ECJ, ${ }^{78}$ European Union law is treated by arbitral tribunals as a matter of fact in the process of ascertaining if it breaches the respective international investment agreement. ${ }^{79}$ It is immaterial from an international perspective whether the measure is based on a competence

\footnotetext{
${ }^{67}$ Opinion of Advocate General Wathelet, Case C-284/16, Slovk. v. Achmea, paras. 49-50, ECLI:EU:C:2017:699 (Sept. 19, 2017).

${ }^{68}$ Achmea, supra note 65 , at paras. 58-60.

${ }^{69} \mathrm{Id}$. at para. 59; Communication from the Commission to the European Parliament and the Council, Protection of intra-EU investment, 3-4, $\operatorname{COM}(2018)$ 547/2 (July 13, 2018). Contra Nagy, supra note 65, at 1006.

${ }^{70}$ Achmea, supra note 65, at para. 50.

${ }^{71}$ The ICSID Convention provides for interpretation (art. 50), revision (art. 51), and annulment of the award (art. 52).

${ }^{72}$ For CETA, see art. 8.41.

${ }^{73}$ Opinion of Advocate General Bot, CETA Opinion, paras. 179, 192, ECLI:EU:C:2019:72 (Jan. 29, 2019).

${ }^{74}$ TFEU art. 216(2). See also Opinion of Advocate General Wathelet, Case C-266/16, Western Sahara Campaign UK v. Commissioners for Her Majesty's Revenue and Customs and Secretary of State for Environment, Food and Rural Affairs, para. 46, ECLI:EU:C:2018:1 (Jan. 10, 2018).

${ }^{75}$ Fisnik Korenica et al., TTIP's Judicature in the Light of Opinion 2/13, 24 EUr. PUB. L. 73, 88 (2018). Opinion of Advocate General Bot, supra note 73, at paras. 122, 155, 167.

${ }^{76}$ VCLT art. 27.

${ }^{77}$ For the review of judicial acts by investment tribunals, see generally BERK DEMIRKOL, JUDICIAL ACTS AND INVESTMENT Treaty Arbitration (2018).

${ }^{78}$ Achmea, supra note 65 , at paras. $40-42$.

${ }^{79}$ Opinion of Advocate General Bot, supra note 73, at para. 134. For CETA, see art. 8.31.2; for the Trans-Pacific Partnership, see art. 9.25.1, fn. 34 .
} 
of the European Union or the Member States. ${ }^{80}$ Not implementing arbitral awards, and instead subjecting them to a preliminary ruling procedure, would be inconsistent with Articles 53(1) and 54(1) of the ICSID Convention and Article III of the New York Convention ${ }^{81}$ _depending on the arbitration regime chosen-which stipulate that arbitral awards are enforceable in the domestic legal systems.

That said, the fact that the European Union has also concluded CETA-and not the Member States alone-makes a difference. ${ }^{82}$ In Achmea the ECJ reasoned:

In the present case, however, apart from the fact that the disputes falling within the jurisdiction of the arbitral tribunal referred to in Article 8 of the BIT may relate to the interpretation both of that agreement and of EU law, the possibility of submitting those disputes to a body which is not part of the judicial system of the EU is provided for by an agreement which was concluded not by the EU but by Member States. Article 8 of the BIT is such as to call into question not only the principle of mutual trust between the Member States but also the preservation of the particular nature of the law established by the Treaties, ensured by the preliminary ruling procedure provided for in Article $267 \mathrm{TFEU}$, and is not therefore compatible with the principle of sincere cooperation ...83

As Advocate General Bot pointed out in Opinion 1/17, considerations of mutual trust and sincere cooperation are irrelevant in the relationship with third countries: ${ }^{84}$ "EU law does not require trust in the judicial systems of third States, regardless of the level of reliability of the judicial system in those States." ${ }^{85}$ The ECJ followed this line of reasoning, thus distinguishing intra-EU ISDS from ISDS with third countries. ${ }^{86}$ Notwithstanding Opinion 1/17, the ECJ-by insisting on safeguarding the preliminary ruling procedure in Article 267 of the TFEU-makes it difficult for the European Union to accept the jurisdiction of international courts outside the EU judicial framework if those courts provide legal standing to individuals. ${ }^{87}$ This is questionable.

\section{General Prohibition of Discrimination on Grounds of Nationality}

Because it found that an intra-EU ISDS mechanism is not compatible with the autonomy of EU primary law, ${ }^{88}$ the ECJ could leave the question open if such a mechanism is also discriminatory within the meaning of Article 18(I) of the TFEU vis-à-vis other EU investors that do not have access to it. On a related note, unlike the Advocate General, ${ }^{89}$ the European Commission is of the view that intra-EU BITs are discriminatory: "[I]ntra-EU BITs conflict with the principle of non-discrimination among EU investors within the Single Market by conferring rights on a bilateral basis to investors from some Member States only." 90 The rights that intra-EU BITs confer are

\footnotetext{
${ }^{80}$ For the determination of the respondent for disputes with the European Union or its Member States in CETA, see art. 8.21 .

${ }^{81}$ Convention on the Recognition and Enforcement of Foreign Arbitral Awards, June 10, 1958, 21 U.S.T. 2517.

${ }^{82}$ In the affirmative, Masdar Solar \& Wind Cooperatief U.A. v. Kingdom of Spain, ICSID Case No. ARB/14/1, Award, para. 679 (May 16, 2018); Jörg Gundel, Investitionsschutz-Schiedsgerichtsbarkeit und Unionsrecht nach dem Achmea-Urteil des EuGH, EUROPÄISCHES WIRTSCHAFTS- UND STEUERRECHT 124, 128 (2018); Lang, supra note 52, at 43, 45-47, 49-50.

${ }^{83}$ Achmea, supra note 65 , at para. 58 (emphasis added).

${ }^{84}$ Opinion of Advocate General Bot, supra note 73, at paras. 107-9, 208.

${ }^{85} \mathrm{Id}$. at fn. 101.

${ }^{86}$ CETA Opinion, supra note 6, at paras. 126-29.

${ }^{87}$ Cf. ECJ, Opinion 2/13, para. 258, ECLI:EU:C:2014:2454, Judgment of 18 Dec. 2014; Opinion 1/09, 2011 E.C.R. I-1137, para. 89.

${ }^{88}$ Achmea, supra note 65 , at paras. 59-61.

${ }^{89}$ Opinion of Advocate General Wathelet, supra note 67, at para. 82.

${ }^{90}$ European Commission Press Release MEMO/18/4529: Commission provides guidance on protection of cross-border EU investments - Questions and Answers, EUROPEAN COMMIssion (July 19, 2018), https://ec.europa.eu/commission/presscorner/ detail/en/MEMO_18_4529.
} 
of a procedural nature as well and include the right of "an investor from one Contracting Party to bring proceedings before an arbitral tribunal in the event of a dispute with the other Contracting Party." "91 Advocate General Wathelet, by contrast, denying discrimination within the meaning of Article 18(I) of the TFEU, argued that "the fact that the reciprocal rights and obligations created by the BIT apply only to investors from one of the two Contracting Member States is a consequence inherent in the bilateral nature of BITs," and that ISDS "is not a benefit separable from the remainder of the BIT." ${ }^{2}$ In the same vein, an arbitral tribunal held that "[t]he fact that, when there is a BIT, such national remedy is replaced or supplemented by an international arbitration mechanism does not ... involve any discrimination ...." Im Importantly, in Achmea, the problem was that investors from third EU countries could not bring a case and the ensuing issue was whether that amounted to discrimination on grounds of nationality, or in other words, whether Article 18(I) of the TFEU not only guarantees national treatment but also most-favored-nation treatment.

The constellation in casu is different: The complaining investor is a national of the respondent state, so the issue is that nationals cannot institute proceedings against their own government. According to the prevailing view, Article 18(I) of the TFEU does not cover reverse discrimination because it only applies "[w]ithin the scope of application of the Treaties," that is, cross-border situations. ${ }^{94}$ The ECJ consistently holds that the prohibition of discrimination on grounds of nationality:

[M]ay be invoked only where the case in question comes within the area to which [EU] law applies .... Not only does that conclusion emerge from the wording of those articles, but it also accords with their purpose, which is to assist in the abolition of all obstacles to the establishment of a common market in which the nationals of the Member States may move freely within the territory of those states in order to pursue their economic activities. ${ }^{95}$

On that point, the ECJ ruled in Vatsouras and Koupatantze-which concerned "the withdrawal of basic benefits in favour of job-seekers"-that Article 18(I) of the TFEU "does not preclude national rules which exclude nationals of Member States of the European Union from receipt of social assistance benefits which are granted to nationals of nonmember countries." 96

\section{Discrimination of Nationals}

\section{International Law Position}

The international law position is encapsulated in the Hopkins case mentioned above: Discrimination of nationals would be unproblematic from the vantage of international law, even if true, just like national constitutional law would not be concerned about foreigners being unable to participate in the political will formation of the host state to the same extent as nationals. If it were different, international law would encroach on national sovereign powers. ${ }^{97}$ It is thus a corollary of the deference shown by international law to national lawmakers to be indifferent to the

\footnotetext{
${ }^{91}$ Achmea, supra note 65 , at headline.

${ }^{92}$ Opinion of Advocate General Wathelet, supra note 67, at paras. 75-76.

${ }^{93}$ Rupert Joseph Binder v. Czech, UNCITRAL, Award on Jurisdiction, para. 65 (June 6, 2007).

${ }^{94}$ Lorenzmeier, supra note 66, at para. 5; Epiney, supra note 29, at paras. 30, 32; Rust, supra note 14, at paras. 47-48.

${ }^{95}$ ECJ, Joined Cases C-35/82 \& C-36/82, Morson and Jhanjan v. State of the Netherlands, para. 15, ECLI:EU:C:1982:368, Judgment of 27 Oct. 1982. See also Case C-206/91, Koua Poirrez v. Caisse d'allocations familiales de la Seine-Saint-Denis, 1992 E.C.R. I-6685, para. 10.

${ }^{96}$ Joined Cases C-22/08 \& C-23/08, Athanasios Vatsouras and Josif Koupatantze v. Arbeitsgemeinschaft (ARGE) Nürnberg 900, 2009 E.C.R. I-4585, paras. 2, 53.

${ }^{97}$ For the equivalent problem in the relationship between the European Union and its Member States, see Bösch, supra note 29 , at 96 .
} 
treatment of nationals, unless that treatment falls below the level of international human rights standards binding upon the states. ${ }^{98}$

In 1926, the arbitral tribunal in the Harry Roberts case coined the proposition that foreigners are entitled to a degree of protection that may well be above the degree afforded to nationals: "[E] quality [of treatment of aliens and nationals] is not the ultimate test of the propriety of the acts of authorities in the light of international law. The test is, broadly speaking, whether aliens are treated in accordance with ordinary standards of civilization." 99 This is the very essence of an "international minimum standard." 100 The crux of the matter is how domestic law reacts to that.

\section{Differential Treatment}

\section{Comparability: Opinion 1/17}

Comparability is a precondition for any claim of discrimination. ${ }^{101}$ The principle of equality before the law purports that the legislature treats as equal what is basically equal and treats as different what is basically different-without predetermining the comparators. ${ }^{102}$ The notion that the legislature is under an obligation to ensure that identical treatment is available to all similarly situated investors is based in this principle. ${ }^{103}$ This makes the formation of relevant comparison groups necessary. ${ }^{104}$ So which is the right comparison: The treatment of national investors as compared to (a) foreign investors in the host state or (b) other nationals investing in the territory of another contracting party? In concreto, are German investors to be compared with Canadians investing in Germany or with fellow Germans investing in Canada?

\subsection{Differences Between National and Foreign Investors}

The ECJ in Opinion 1/17, among other things, reviewed the compatibility of the CETA investorstate dispute resolution system in light of Articles 20 and 21(2) of the Charter of Fundamental Rights of the European Union. Article 20 of the Charter stipulates equality before the law, and Article 21(2) of the Charter contains the general prohibition of discrimination on grounds of nationality. Yet, because the scope of Article 21(2) is congruent with the scope of Article 18(I) of the TFEU, and, as mentioned above, that provision does not capture the constellation at hand, the analysis pivoted on Article 20 of the Charter. ${ }^{105}$ In this respect, the Court apodictically denied the comparability of foreign and national investors:

\footnotetext{
${ }^{98}$ See Charter of the United Nations art. 2(7), June 26, 1945, 1 U.N.T.S. 16.

${ }^{99}$ Harry Roberts (U.S.) v. United Mexican States, 4 RIAA 77, 80, para. 8 (Nov. 2, 1926).

${ }^{100}$ Krista Nadakavukaren Schefer, International Investment Law: Text, Cases and Materials 423 (2nd ed. 2016).

${ }^{101}$ CETA Opinion, supra note 6, at para. 177, concerning Charter of Fundamental Rights art. 20; Case C-148/02, Carlos Garcia Avello v. Belgian State, 2003 E.C.R. I-11613, para. 31, concerning TFEU art. 18.

${ }^{102}$ Bundesverwaltungsgericht [BVerwG] [Federal Constitutional Court], 1 BvR 3262/07, para. 150 (July 30, 2008), https:// www.bverwg.de/suche?lim $=10 \& \operatorname{start}=1 \& \mathrm{db}=\mathrm{e} \& \mathrm{q}={ }^{\star} \& \mathrm{dt}=$. See also Pietzcker, supra note 29, at para. 20. For the similar definition of the principle of equal treatment in European Union law, see CETA Opinion, supra note 6, at para. 176 ("[C]omparable situations must not be treated differently and different situations must not be treated in the same way, unless such treatment is objectively justified ....").

${ }^{103}$ For the analogous argumentation in World Trade Organization (WTO) law, see Appellate Body Report, European Communities-Conditions for the Granting of Tariff Preferences to Developing Countries, WT/DS246/AB/R, para. 173 (adopted Apr. 20, 2004), concerning the exegesis of "non-discriminatory" in para. 2(a), fn. 3 of the Decision on Differential and More Favourable Treatment, Reciprocity and Fuller Participation of Developing Countries [Enabling Clause] (Nov. 28, 1979), GATT Doc. BISD 26S/203.

${ }^{104}$ Pietzcker, supra note 29 , at para. 3.

${ }^{105}$ CETA Opinion, supra note 6 , at paras. $168-71$.
} 
Canadian enterprises and natural persons that invest within the Union are ... in a situation that is comparable to that of enterprises and natural persons of Member States that invest in Canada, their situation is not, on the other hand, comparable to that of enterprises and natural persons of Member States that invest within the Union. ${ }^{106}$

As noted by Advocate General Bot, foreign investors are "subject to different rules" and have also assumed different risks and costs. ${ }^{107}$ For foreigners it is about opportunity costs. ${ }^{108}$ This finding is borne out by the purpose of Chapter 8 of the CETA, "which is to protect the investors of each Party from the disadvantages that they might suffer by investing in the other Party."109

It is worth recalling that, in connection with Article 3.1 of the Agreement on Trade-Related Aspects of Intellectual Property Rights, ${ }^{110}$ the panel in EC-Trademarks and Geographical Indications observed that the proper standard of comparison for purposes of determining discrimination was "the nationals ... who seek opportunities with respect to the same type of intellectual property in comparable situations." 111 At first blush, both groups-national and foreign investors - are comparable: They may be direct competitors, operate in the same business sector, and even trade in identical products. Nevertheless, foreign investors face risks that national investors do not. By the same token, Advocate General Bot based his argument on the fact that there is a significant difference between investing in one's own country and a foreign jurisdiction. According to Dolzer and Schreuer, foreign investors often "sink substantial resources into the project at the outset of the investment;" 12 then "the money sunk into the project at the outset typically cannot be used subsequently at another location because the machinery and installations of the project are specifically designed and tied to the particularities of the project and its location." 113 They further stress that "[o]nce ... the investor's resources are sunk into the project, the dynamics of influence and power tend to shift in favour of the host state." 114 Foreign investors choose to enter into a new relationship with the host state, while national investors are fully integrated into their home jurisdiction. ${ }^{115}$ Foreign investors, by contrast, are subject to at least two legal orders - the one of the host state as well as the one of their home state.

\subsection{Different Normgivers}

In the same vein, Article 3(1) of the Basic Law does not apply to situations in which the differential treatment can be ascribed to two legislatures setting different rules. ${ }^{116}$ When Germans invest in Canada, they are subject to Canadian jurisdiction and consequently governed by Canadian law. A violation of the principle of equality before the law, however, presupposes the unequal treatment by the same legislature. The German state, therefore, cannot be held accountable when the Canadian government treats Germans differently than the German government would in the

\footnotetext{
${ }^{106} I d$. at para. 180 .

${ }^{107}$ Opinion of Advocate General Bot, supra note 73, at paras. 203, 207.

${ }^{108}$ Sergio Puig \& Gregory Shaffer, Imperfect Alternatives: Institutional Choice and the Reform of Investment Law, $112 \mathrm{AM}$. J. INT'L L. 361, 372 (2018).

${ }^{109}$ Opinion of Advocate General Bot, supra note 73, at para. 208.

${ }^{110}$ WTO Agreement on Trade-Related Aspects of Intellectual Property Rights, Including Trade in Counterfeit Goods, Apr. 15, 1994, 1869 U.N.T.S. 299.

${ }^{111}$ Panel Report, European Communities-Protection of Trademarks and Geographical Indications for Agricultural Products and Foodstuffs (U.S.), WT/DS174/R, para. 7.181 (adopted Apr. 20, 2005).

${ }^{112}$ Dolzer \& Schreuer, supra note 51 , at 21.

${ }^{113} I d$.

${ }^{114} I d$. at 22. See also Salacuse, supra note 10, at 254-55.

${ }^{115} \mathrm{Cf}$. Jörg Gundel, Die Inländerdiskriminierung zwischen Verfassungs- und Europarecht: Neue Ansätze in der deutschen Rechtsprechung, Deutsches Verwaltungsblatt 269, 272 (2007).

${ }^{116}$ Thorsten Kingreen \& Ralf Poscher, Grundrechte - StaAtsrecht II, para. 518 (34th ed. 2018); Jarass, supra note 29, at para. 13; Pietzcker, supra note 29, at para. 93. See also Bundesverfassungsgericht [BVerfG] [Federal Constitutional Court], 1 BvR 931/12, Jan. 14, 2015, para. 61.
} 
same situation. That it is only a specific subset of nationals that benefit from ISDS-those with overseas investments - is immaterial; nationals with no overseas investment cannot be affected by a breach of Sections C and D of Chapter 8 of the CETA by the other Party in any event. ${ }^{117}$

\section{Formally Different Treatment but Equivalent Judicial Relief?}

Because the ECJ denied comparability in Opinion 1/17, it could stop at this point. Au contraire, the Advocate General reasoned, in the alternative, that:

[E]ven if Canadian investors who make investments within the European Union and EU investors who make investments within the European Union should be regarded as being in a comparable situation, the fact that only the first category of investors can benefit from the investor-State dispute settlement mechanism established by the CETA is objectively justified ... 118

Here, the Advocate General skipped one step in his legal analysis. Before addressing justifiability, one could already ask if the different treatment of foreign investors accords an advantage in comparison to national investors. If not, one can deny discrimination on that basis; a justification of the differential treatment would no longer be called for.

Whether a particular case can be heard by a court or tribunal depends on the rules of jurisdiction and the subject matter of the dispute. The scope of the CETA Tribunal is set out in Article 8.18 of the CETA. Notably, market access is non-actionable. Access to the investment tribunal is conditional upon having invested in the territory of the other Party. Thus, Germans can gain access to the Tribunal by investing in Canada, but they could not challenge German government measures, only Canadian ones.

All specialized courts - be they national or international-have, by their nature, access requirements without any assertion that this is at variance with the principle of equality before the law. If a matter does not relate to an employment issue, it could not be brought before the labor courts; conversely, a labor dispute could not be litigated before the family courts, and so on. That a complainant must show legal standing is a procedural requirement widely recognized in national and international law. ${ }^{119}$ Furthermore, a guarantee of multiple instances cannot be derived from Article 3 of the Basic Law; only in criminal procedures does Article 14(5) of the ICCPR assure a review process. In the final analysis, the mere existence of additional-jurisdictional-requirements does not eo ipso lead to the conclusion that national investors are discriminated against. ${ }^{120}$ What matters is the actual position within the legal order. ${ }^{121}$

In line with the German case law on reverse discrimination, ${ }^{122}$ Voss considers reverse discrimination to be legitimate as long as it does not cause competitive distortions in the territory of the host state. ${ }^{123}$ He submitted in relation to tender processes that:

\footnotetext{
${ }^{117}$ See CETA art. 8.18.1.

${ }^{118}$ Opinion of Advocate General Bot, supra note 73, at para. 209.

${ }^{119}$ For international law, see Barcelona Traction, Light and Power Company Ltd. (Belg. v. Spain), 1970 I.C.J. 3 , 32 para. 35 (Feb. 5).

${ }^{120}$ For a similar line of argument in WTO law, see Appellate Body Report, Thailand-Customs and Fiscal Measures on Cigarettes from the Philippines, WT/DS371/AB/R, para. 130 (adopted July 15, 2011).

${ }^{121}$ Pietzcker, supra note 29 , at paras. $13-14$.

${ }^{122}$ Instead of all, see Jarass, supra note 29 , at para. 97.

${ }^{123}$ Answering this in the affirmative, Stephan W. Schill \& Vladislav Djanic, Wherefore Art Thou? Towards a Public InterestBased Justification of International Investment Law, 33 ICSID Rev. 29, 55 (2018); Gus Van Harten, Key Flaws in the European Commission's Proposals for Foreign Investor Protection in TTIP, 12 OsgoOde LEGAL STUD. Res. PAPER SERIES 1, 3, 6 (2016).
} 
Any preference accorded to some contenders tends to translate into "reverse discrimination" of other contenders .... BIT protection accords protection to beneficiary investors in addition to the protection afforded to domestic investors and foreign investors without BIT protection by the laws of the host country. This is legitimate. ${ }^{124}$

Later on, he maintained that, inter alia, the right to fair competition "militates against developing a protection level under the FET standard which grants BIT protected investors a competitive advantage over their contenders without such protection. Added protection can distort competition." 125 From this, it follows that treating national investors formally different from foreign investors does not, in and of itself, violate the principle of equality before the law either. ${ }^{126}$ For having access to different adjudicatory bodies may have no impact on the quality of remedies available.

This begs the question of whether national investors, not being able to use ISDS, have equal chances to get redress as foreign investors do. In other words, does the differential treatment of national investors, as compared to foreign investors, reduce their prospects of justice? If not, such differential treatment is not perforce discriminatory. ${ }^{127}$ As an aside, the Advocate General in the CETA Opinion had little doubt that the law of the European Union and its Member States "contains adequate standards of protection." 128 The second sentence of Point 6(a) of the CETA Joint Interpretative Instrument, being an instrument within the meaning of Article 31(2)(b) of the VCLT, ${ }^{129}$ affirms that the "CETA will not result in foreign investors being treated more favourably than domestic investors."

It bears emphasizing that the issue is if nationals are disadvantaged vis-a-vis foreigners. ${ }^{130}$ To answer this, the problem has to be assessed from different angles, in terms of stages of appeal, remedies, causes of action, length of procedures, and limitations.

\subsection{Stages of Appeal}

The International Court of Justice, in its Advisory Opinion in Judgment No. 2867 of the Administrative Tribunal of the International Labour Organization, addressed the principle of equality of access to courts and tribunals. Referring to the Human Rights Committee General Comment No. 32 on the Right to Equality before Courts and Tribunals and to a Fair Trial, the Court stressed that "if procedural rights are accorded they must be provided to all the parties unless distinctions can be justified on objective and reasonable grounds." ${ }^{131}$ With respect to ISDS procedures, it observed that "both parties - and not just one-are able to seek interpretation, revision or annulment of the award." 132 What seems to be "key to equality was the same ability to appeal (or to seek annulment) of that initial decision." 133

\footnotetext{
${ }^{124}$ Lemire v. Ukr. (II), ICSID Case No. ARB/06/18, Award, Dissenting Opinion of Jürgen Voss, vi-vii (Mar. 28, 2011).

${ }^{125} \mathrm{Id}$. at vii.

${ }^{126} \mathrm{Cf}$. General Agreement on Trade in Services art. XVII:2, Apr. 15, 1994, 1869 U.N.T.S. 183 (concerning national treatment).

${ }^{127}$ Bundesverwaltungsgericht [BVerwG] [Federal Administrative Court], 8 C 50.12, para. 45 (Apr. 9, 2014); Jarass, supra note 29 , at para. 18 .

${ }^{128}$ Opinion of Advocate General Bot, supra note 73, at para. 252 fn. 177.

${ }^{129}$ Statement by the Council Legal Service on the legal nature of the Joint Interpretative Instrument, 2017 O.J. (L 11) 9, 22. See also preamble to the Joint Interpretative Instrument rec. (e).

${ }^{130}$ For the concept of "disadvantage" within BASIC LAW art. 3(1), see Jarass, supra note 29, para. 14.

${ }^{131}$ Judgment No. 2867 of the Administrative Tribunal of the International Labour Organization Upon a Complaint Filed Against the International Fund for Agricultural Development, Advisory Opinion, 2012 I.C.J. 10, 27 (Feb. 1).

${ }^{132} I d$. at 29.

${ }^{133}$ Int'l Law Ass'n Committee on Rule of Law \& Int'l Inv. Law, Conference Report Sydney, 22 (2018), http://www.ila-hq.org/ index.php/committees.
} 
As a preliminary point, it should be noted that it is Canadian law that determines who is a Canadian and German law that determines who is a German, respectively. ${ }^{134}$ That being said, CETA contains a stand-alone definition of an "enterprise of a Party," making constitution or organization under the laws of the Party, the nationality of which is claimed as the decisive criterion. $^{135}$

As to the German context, both German and foreign investors can take legal action against German government measures before German courts in accordance with Article 19(4) of the Basic Law, which states, in relevant part, as follows: "Should any person's rights be violated by public authority, he may have recourse to the courts. If no other jurisdiction has been established, recourse shall be to the ordinary courts." To be able to bring the same case before the CETA Tribunal, however, a foreign investor would have to withdraw or discontinue "any existing proceeding before a tribunal or court under domestic or international law with respect to a measure alleged to constitute a breach referred to in its claim" and waive "its right to initiate any claim or proceeding before a tribunal or court under domestic or international law" with respect to the said measure. ${ }^{136}$ This forecloses parallel proceedings.

Foreign investors, if organized as juridical persons, are precluded from bringing a case before the German constitutional court by virtue of Article 19(3) of the Basic Law, which restricts the invocability of constitutional basic rights, such as the right to property in Article 14 of the Basic Law, to "domestic artificial persons." 137 The difference in treatment concerns the forum of litigation — constitutional court instead of investment tribunal—rather than the number of instances available to foreign and national investors. Just as foreign artificial persons do not have access to the constitutional court, nationals do not have access to an investment tribunal. In addition, both groups have access to the European Court of Human Rights given the ECHR's broad personal scope of application. ${ }^{138}$ Article 1 of the ECHR provides that "[ $\left.\mathrm{t}\right]$ he High Contracting Parties shall secure to everyone within their jurisdiction the rights and freedoms defined in Section I of this Convention."139

In this context, it should be recalled that the domestic subsidiary of a foreign investor could rely on Article 14 of the Basic Law. ${ }^{140}$ The same is true of individual shareholders. ${ }^{141}$ Under some investment regimes, a subsidiary in the territory of another contracting party can institute investment proceedings against measures of the home state of the holding company. ${ }^{142}$ Under the CETA, the definition of "investor" in Article 8.1 excludes "a branch or a representative office." Thus, a branch or a representative office is barred from taking legal action against measures of the home state of the parent company. Yet, there is a difference between subsidiary, branch and representative offices in terms of legal status and independence from the parent company. ${ }^{143}$

\footnotetext{
${ }^{134}$ See Burkhard Hess, The Private-Public Divide in International Dispute Resolution, 388 RECUEIL DES COURS 49, 152 (2016); Engela C Schlemmer, Investment, Investor, Nationality, and Shareholders, in THE OXFORD HANDBOOK OF INTERNATIONAL INVESTMENT LAW 71, 77 (Peter Muchlinski et al. eds., 2008); NADAKAVUKAREN SCHEFER, supra note 100, at 137.

${ }^{135}$ CETA art. 8.1.

${ }^{136}$ CETA art. 8.22.1(f), (g).

${ }^{137}$ The German constitutional court makes an exception when foreign artificial persons exercise their freedom of establishment under European Union law, with a view to ensuring equality of arms between European artificial persons and their German competitors, See Bundesverfassungsgericht [BVerfG] [Federal Constitutional Court], 1 BvR 2821/11, Dec. 6, 2016, paras. 196-201, https://www.bundesverfassungsgericht.de/SharedDocs/Entscheidungen/EN/2016/12/rs20161206_1bvr282111en.html.

${ }^{138}$ ECHR art. 34.

${ }^{139}$ Emphasis added.

${ }^{140}$ See BASIC LAW art. 19(3). See also Bundesverfassungsgericht [BVerfG] [Federal Constitutional Court], 1 BvR 1916/09, Jul. 19, 2011, para. 69.

${ }^{141}$ See Jarass, supra note 29 , at para. 21.

${ }^{142}$ See Tokios Tokeles v. Ukr., ICSID Case No. ARB/02/18, Decision on Jurisdiction (Apr. 29, 2004); Rompetrol Group N.V. v. Rom., ICSID Case No. ARB/06/3, Decision on Respondent's Preliminary Objections on Jurisdiction and Admissibility (Apr. 18, 2008).

${ }^{143}$ See, e.g., Singapore Branch vs Subsidiary vs Representative Office, GUIDEMESINGAPORE (2019), https://www.guideme singapore.com/business-guides/incorporation/foreign-company-registration/singapore-branch-vs-subsidiary-vs-rep-office.
} 


\subsection{Remedies}

By the same token, domestic law may make available the same remedies as an international investment agreement. It is a difficult task to compare domestic with international remedies, as litigants are motivated by more than just the money amount awarded. ${ }^{144}$ As indicated by the wording of Article 8.39.1 of the CETA, ${ }^{145}$ the remedies available under the CETA are limited to:

(a) monetary damages and any applicable interest;

(b) restitution of property, in which case the award shall provide that the respondent may pay monetary damages representing the fair market value of the property at the time immediately before the expropriation, or impending expropriation became known, whichever is earlier, and any applicable interest in lieu of restitution ....

In consequence, the reversal of the measure at issue is not possible under the CETA. ${ }^{146}$ Additionally, the CETA Tribunal may order interim measures. ${ }^{147}$

German law provides for compensation in the event of expropriation, ${ }^{148}$ as underpinned by the second sentence of Article 1(1) of the Protocol to the ECHR, ${ }^{149}$ damages in cases of administrative injustice, ${ }^{150}$ and restitution. ${ }^{151}$ Although Germany has quite an elaborate state liability law, the options to claim monetary damages in situations of legislative injustice are restricted. ${ }^{152}$ European Union law, by contrast, provides for non-contractual liability in the event of "any damage caused by its institutions or by its servants in the performance of their duties."153

Hoffmann found that the amount of compensation granted under domestic law is generally lower than what can be achieved under international investment law. ${ }^{154}$ Both the Federal Constitutional Court and the European Court of Human Rights held that compensation may remain below the full market value. ${ }^{155}$ At this juncture, it should be noted that German courts take pertinent rulings of the European Court of Human Rights into account. ${ }^{156}$ Having said that,

\footnotetext{
${ }^{144}$ See Martins Paparinskis, Investors' Remedies Under EU Law and International Investment Law, 17 J. WORLD INV. \& TRADE 919, 940-41 (2016) (denying the commensurability of remedies under domestic and international investment law). ${ }^{145}$ CETA art. 8.39.1 (“[T] he Tribunal may only award, separately or in combination ....”) (emphasis added).

${ }^{146}$ The reversal is not possible under any other international investment agreement for that matter. See Chase, supra note 19 , at 222 .

${ }^{147}$ CETA art. 8.34.

${ }^{148}$ BASIC LAW art. 14(3).

${ }^{149}$ Protocol to the Convention for the Protection of Human Rights and Fundamental Freedoms, Mar. 20, 1952, 213 U.N.T.S. 262 [hereinafter the Protocol]. For the scope of the Protocol art. 1, see CHristoph Grabenwarter, European CONVENTION ON Human Rights: Commentary P1-1, paras. 3-6 (2014). On the issue of whether "possessions" within the meaning of the Protocol is the same as "investment," see José E. Alvarez, The Use (and Misuse) of European Human Rights Law in InvestorState Dispute Settlement, in The Impact of EU Law on International Commercial Arbitration 591-92 (Franco Ferrari ed., 2017). On the issue of whether "property" within the meaning of BASIC LAW art. 14 is the same as "investment," see HOFFMANN, supra note 1 , at 310-11.

${ }^{150}$ Hartmut Maurer \& Christian Waldhoff, Allgemeines Verwaltungsrecht, § 27, para. 92 (19th ed. 2017).

${ }^{151} I d$. at $\$ 30$.

${ }^{152} I d$. at $\$ 26$, paras. $52-53$.

${ }^{153}$ TFEU art. 340(2) in conjunction with TFEU art. 268; Charter of Fundamental Rights art. 41(3).

${ }^{154}$ HoffmanN, supra note 1 , at 322-23.

${ }^{155}$ Bundesverfassungsgericht [BVerfG] [Federal Constitutional Court], 1 BvR 638/64, 1 BvR 673/64, 1 BvR 200/65, 1 BvR 238/65, 1 BvR 249/65, Dec. 18, 1968, para. 183, https://opinioiuris.de/entscheidung/1573; James and Others v. The United Kingdom, App. No. 8793/79, para. 54 (Feb. 21, 1986), http://hudoc.echr.coe.int/eng?i=001-57507; Vistiņš and Perepjolkins v. Latvia, App. No. 71243/01, paras. 112-13 (Oct. 25, 2012), http://hudoc.echr.coe.int/eng?i=001-142270.

${ }^{156}$ Bundesverfassungsgericht [BVerfG] [Federal Constitutional Court], 2 BvR 1481/04, Oct. 14, 2004, para. 47, http://www. bundesverfassungsgericht.de/entscheidungen/rs20041014_2bvr148104en.html.
} 
under German law, the measure at issue can be annulled ${ }^{157}$ or-if the measure is an administrative act or a statutory order-its nullity can be established. ${ }^{158}$ In actuality, commensurate with the principle of primacy of primary legal protection, the measure at issue has to be impugned; the person affected could not acquiesce in the measure and instead claim damages. ${ }^{159}$ The rationale is to preserve the prerogative of the legislature to regulate damages for deprivations of property rights. ${ }^{160}$ Furthermore, the administrative courts may issue a rejected or omitted administrative act $^{161}$ and make interim orders. ${ }^{162}$ Importantly, only the Federal Constitutional Court, which does not hear individual complaints by foreign legal persons, has the power to declare a law unconstitutional. ${ }^{163}$ Moreover, should Germany infringe European Union law, it may incur liability on the following three conditions:

[T] he rule of law infringed must be intended to confer rights on individuals; the infringement must be sufficiently serious; and there must be a direct causal link between the breach of the obligation resting on the State and the damage sustained by the injured parties .... ${ }^{164}$

Both German law and the CETA provide for derivative actions. ${ }^{165}$ Cognizant that ownership of shares is one of the specific examples of investment in Article 8.1 of the CETA, ${ }^{166}$ derivative actions under the CETA are only available to controlling shareholders. ${ }^{167}$ It follows that minority non-controlling investors have to show "loss or damage as a result of the alleged breach." 168 CETA expressly distinguishes between the foreign investor's loss or damage, on the one hand, and the loss or damage to a locally established enterprise that the investor owns or controls, on the other hand. ${ }^{169}$ This outcome is equivalent to the "no reflective loss" principle in German law. ${ }^{170}$

Taking all into account, the constitutional court may find that national investors are not put at a disadvantage in Germany when compared to foreign investors, as German law equips nationals with more far-reaching remedies — in the form of a rescissory or enforcement action. ${ }^{171}$ We will now turn to the available causes of action, notably fair and equitable treatment ("FET"). Being an idiosyncratic international standard, an FET claim does not exist in domestic law. The arbitral

\footnotetext{
${ }^{157}$ Verwaltungsgerichtsordnung [VwGO] [COdE of Administrative Court Procedure] $\$ \$ 42,113(1)$ (if the measure is an administrative act), available at https://www.gesetze-im-internet.de/englisch_vwgo/index.html; VERWALTUNGSGerichtsordnung [VwGO] [COde of Administrative Court Procedure] $\$ 47(5)$ (if the measure is a by-law or a statutory order); Act on the Federal Constitutional Court $\$ \$ 13$ No. 8a, 31(2), 95(3) (if the measure is a law).

${ }^{158}$ Verwaltungsgerichtsordnung [VwGO] [Code of Administrative Court Procedure] $\$ 43$. According to the prevailing view, section 43 also encompasses statutory orders under the heading of "non-existence of a legal relationship," See MAURER \& WALDHOFF, supra note 150, at $\$ 13$, para. 21.

${ }^{159}$ HoffmanN, supra note 1 , at 320 .

${ }^{160} \mathrm{Id}$. at 321 .

${ }^{161}$ Verwaltungsgerichtsordnung [VwGO] [Code of Administrative Court Procedure] \$\$ 42, 113(5).

${ }^{162} I d$. at $\$ \$ 80 \mathrm{a}(3), 123$.

${ }^{163}$ BASIC LAW art. 100(1).

${ }^{164}$ ECJ, Case C98/14, Berlington Hungary \& Others v. Magyar Állam, para. 104, ECLI:EU:C:2015:386, Judgment of 11 June 2015 (references omitted).

${ }^{165} \mathrm{See}$ Aktiengesetz [Stock Corporation Act] $\$ \$ 148-49$, available at https://www.gesetze-im-internet.de/englisch_aktg/ index.html.

${ }^{166}$ CETA art. 8.1(b).

${ }^{167}$ CETA art. 8.23.1(b) ("an investor of a Party, on behalf of a locally established enterprise which it owns or controls directly or indirectly”) (emphasis added).

${ }^{168} \mathrm{Id}$. art. 8.18.1.

${ }^{169} \mathrm{Id}$. arts. 8.19.6, 8.22.1, 8.39.3. For the definition of "locally established enterprise," see CETA art. 8.1.

${ }^{170}$ Stock Corporation Act, supra note 165, at $\$ \$ 117(1), 317(1)$ ("shall also be under obligation to compensate the stockholders for the damage they have suffered as a result, insofar as they have suffered damage above and beyond the damage that has been caused them by the damage caused to the company") (emphasis added); Bundesgerichtshof [BGH] [Federal Court of Justice], Mar. 20, 1995, II ZR 205/94, https://opinioiuris.de/entscheidung/3202. See also Bas J. de Jong, Shareholders' Claims for Reflective Loss: A Comparative Legal Analysis, 14 EUR. BUS. ORG. L. Rev. 97, 107 (2013).

${ }^{171} \mathrm{Cf}$. Opinion of Advocate General Bot, supra note 73, para. 168.
} 
tribunal in Achmea v. Slovakia (I) and the Advocate General in Achmea corroborated that for European Union law. ${ }^{172}$ Yet, perfect congruence is not required to satisfy the requirements of Article 3(1) of the Basic Law. ${ }^{173}$

\subsection{Causes of Action}

Under the CETA, the FET standard is highly constricted. ${ }^{174}$ The adjectives_- "fundamental," "manifest" and "targeted"- are indicative of high thresholds. ${ }^{175}$ Against this background, Sattorova submits that "the more recent treaties, by virtue of their revised wording [of FET], may come closer to EU law as far as their protective scope is concerned," 176 given that a right to good administration derives from Article 41 of the Charter of Fundamental Rights of the European Union. It is, however, confined to "the institutions, bodies, offices and agencies of the Union."177

The several components of the FET standard-encapsulating rule of law principles ${ }^{178}$ - can be found in German law, which is the question here. ${ }^{179}$ For instance, Article 6(1) of the ECHR, which has the status of a statute in Germany, ${ }^{180}$ guarantees a fair trial in civil and criminal proceedings, ${ }^{181}$ which is also a requirement in paragraphs (a) and (b) of Article 8.10.2 of the CETA. ${ }^{182}$ This guarantee is buttressed by the right to an effective remedy before a national authority in Article 13 of the ECHR and the tenet of effective judicial protection in European Union law. ${ }^{183}$ Article 1(3) of the Basic Law stipulates that the "basic rights shall bind the legislature, the executive and the judiciary as directly applicable law," and Article 20(3) of the Basic Law ensures that " $[t]$ he legislature shall be bound by the constitutional order, the executive and the judiciary by law and justice." The prohibition of arbitrary state action, as reflected in paragraph (c) of Article 8.10.2 of the CETA, is covered therein as well as in Article 3(1) of the Basic Law. ${ }^{184}$ Article 3(3) of the Basic Law, Article 14 of the ECHR ${ }^{185}$ and the General Act on Equal Treatment ${ }^{186}$ prohibit discrimination on grounds of gender, race, or religious belief, also found in paragraph (d).

${ }^{172}$ Achmea v. Slovk. (I), supra note 50, at para. 250; Opinion of Advocate General Wathelet, supra note 67, at paras. 58, 210, 213-16.

${ }^{173}$ Bundesverwaltungsgericht, supra note 127 , at para. 45; Jarass, supra note 29 , at para. 97.

${ }^{174}$ CETA art. 8.10.2.

${ }^{175}$ Stephan W. Schill \& Heather L. Bray, The Brave New (American) World of International Investment Law: Substantive Investment Protection Standards in Mega-Regionals, in Mega-Regional Trade Agreements 141 (Thilo Rensmann ed., 2017).

${ }^{176}$ Mavluda Sattorova, Investor Rights under EU Law and International Investment Law, 17 J. WORLD INV. \& TRADE 895, 902 (2016).

${ }^{177}$ Charter of Fundamental Rights art. 41(1). For the scope of the Charter, see ECJ, Case C-206/13, Cruciano Siragusa v. Regione Sicilia, para. 31, ECLI:EU:C:2014:126, Judgment of 6 Mar. 2014.

${ }^{178}$ See Campbell McLachlan, Laurence Shore \& Matthew Weiniger, International Investment Arbitration: Substantive Principles, paras. 7.15, 7.109, 7.355 (2nd ed. 2017); Marc Jacob \& Stephan W. Schill, Fair and Equitable Treatment: Content, Practice, Method, in InTernational Investment Law: A Handbook 700, paras. 20, 34, 41, 126, 129, 142, 169 (Marc Bungenberg et al. eds., 2015); Reinhard Quick, Warum wir ISDS in TTIP brauchen, 18 ZEITSCHRIFT FÜr Europarechtliche Studien 277, 291 (2015); Kenneth J. Vandevelde, A Unified Theory of Fair and Equitable Treatment, 43 N.Y.U.J. INT'L L. \& PoL. 43, 49-53 (2010).

${ }^{179}$ For the equivalent analysis under European Union law, see Gloria M. Alvarez, Redefining the Relationship Between the Energy Charter Treaty and the Treaty of Functioning of the European Union: From a Normative Conflict to Policy Tension, 33 I.C.S.I.D. REV. 560, 576 (2018).

${ }^{180}$ BASIC LAW art. 59(2).

${ }^{181}$ Not administrative proceedings "relating to matters at the very heart of public law," see Grabenwarter, supra note 149, Art. 6, at para. 11. This is interpreted narrowly, however; for example, tax penalties would come under ECHR art. 6(1), see Neftyanaya Kompaniya Yukos v. Russia, App. No. 14902/04, para. 452 (Jan. 29, 2009), http://hudoc.echr.coe.int/eng?i=001-106308.

${ }^{182}$ For procedural fairness in relation to the protection of property in Germany, see Jarass, supra note 29, at para. 47(a).

${ }^{183}$ Treaty on European Union art. 19(1); TFEU art. 340; Charter of Fundamental Rights art. 47.

${ }^{184}$ Bundesverfassungsgericht [BVerfG] [Federal Constitutional Court], 1 BvL 34/81, Oct. 5, 1993, paras. 26, 39; Bundesverfassungsgericht [BVerfG] [Federal Constitutional Court], 1 BvL 21/12, Dec. 17, 2014, para. 122.

${ }^{185}$ According to Protocol art. 5, ECHR art. 14 also applies to property rights in Protocol art. 1.

${ }^{186}$ Allgemeines Gleichbehandlungsgesetz [AGG] [General Act on Equal Treatment], Aug. 14, 2006, \$\$ 1, 19, available at https://www.gesetze-im-internet.de/englisch_agg/index.html. 
Furthermore, national investors are protected from abusive treatment, just like foreign investors are under paragraph (e): The German Criminal Code penalizes the use of "threats or force to cause a person to do, suffer or omit an act" 187 and contracts made with the government under duress are voidable. ${ }^{188}$ Legal transactions contrary to public policy, which include transactions contrary to basic rights, ${ }^{189}$ are void. ${ }^{190}$ In addition, the German Civil Code proscribes the exercise of a right "if its only possible purpose consists in causing damage to another."191

All of this shows that nationals find equal protections in German law, even exceeding the relatively low standard set by Article 8.10 of the CETA. On top of that, the constitutional rule of law principles are backed up by the requirements of European Union law, for example, as regards legal certainty ${ }^{192}$ and due process, ${ }^{193}$ which benefit national investors, at least indirectly. ${ }^{194}$

\subsection{Length of Procedures and Limitations}

Foreign investors' rights are different, but not necessarily better. Nevertheless, national procedures take considerably longer than ISDS procedures. So foreign investors have a time advantage, as they can go directly to the investment court, provided that they give a waiver pursuant to Article 8.22.1 (g) of the CETA. Before domestic artificial persons can go to the constitutional court, they first have to exhaust all other remedies. ${ }^{195}$ Yet, as seen above, the government measure at issue can be annulled and a specific action can be requested under domestic law, which is more than what can be achieved under the CETA. The open question is whether the stronger remedies warrant the lengthy procedures. ${ }^{196}$ What is clear is that complainants would be ill-advised to argue that ISDS is discriminatory because the domestic system is inefficient, something that is the responsibility of the host state to address. For this would provide the perfect justification for ISDS.

Further differences exist as to the limitation of actions. Article 8.19.6 of the CETA provides as follows:

A request for consultations must be submitted within:

(a) three years after the date on which the investor ... first acquired or should have first acquired, knowledge of the alleged breach and knowledge that the investor ... has incurred loss or damage thereby; or

\footnotetext{
${ }^{187}$ Strafgesetzbuch [STGB] [Penal Code], Nov. 13, 1998, \$240, available at https://www.gesetze-im-internet.de/englisch_ stgb/englisch_stgb.html.

${ }^{188}$ See Verwaltungsverfahrensgesetz [VwVFG] [Administrative Procedures Act], May 25, 1976, $\$ 59$, available at https:// www.bmi.bund.de/SharedDocs/downloads/EN/gesetztestexte/VwVfg_en.html; Bürgerliches Gesetzbuch [BGB] [CIVIL CODE] $\$ \$ 123,142$, available at https://www.gesetze-im-internet.de/englisch_bgb/.

${ }^{189}$ Palandt, Bürgerliches Gesetzbuch, $\$ 138$, paras. 4, 13, 42 (78th ed. 2019). See, e.g., Bundesgerichtshof [BGH] [Federal Court of Justice], Apr. 26, 1972, IV ZR 18/71, para. 9.

${ }^{190}$ Verwaltungsverfahrensgesetz [VwVFG] [Administrative Procedures Act] $\$ 59$; Bürgerliches Gesetzbuch [BGB] [CIVIL CODE] $\$ 138$.

${ }^{191}$ Bürgerliches Gesetzbuch [BGB] [CIVIL CODE] $\$ 226$.

${ }^{192}$ ECJ, Case C-318/10, SIAT v. Belgium, para. 58, ECLI:EU:C:2012:415, Judgment of 5 July 2012; Case C-169/07, Hartlauer Handelsgesellschaft mbH v. Landesregierung, 2009 E.C.R. I-1721, para. 64; Case C-483/99, Comm'n v. France, 2002 E.C.R. I-4781, para. 50.

${ }^{193}$ Case C-349/07, Sopropé v. Fazenda Pública, 2008 E.C.R. I-10369, paras. 36-37 (analyzing the right to be heard); Case C-19/92, Dieter Kraus v. Land Baden-Württemberg, 1993 E.C.R. I-1663, para. 40 (holding that adverse decisions by national authorities must give reasons and are subject to judicial review).

${ }^{194} C f$. Case C-245/09, Omalet v. Rijksdienst voor Sociale Zekerheid, 2010 E.C.R. I-13771, para. 15 (“[E]ven in ... a purely internal situation, the Court's answer may nevertheless be useful to the referring court, in particular if its national law required it to grant the same rights to a national of a given Member State as those which a national of another Member State in the same situation would derive from European Union law.").

${ }^{195}$ See BASIC LAW art. 94(2); Act on the Federal Constitutional Court $\$ 90(2)$.

${ }^{196}$ See Bundesverfassungsgericht [BVerfG] [Federal Constitutional Court], 1 BvL 29, 30, 33, 34, 36/83, Nov. 18, 1986, para. 68 (considering the offsetting of less favorable treatment of a group of people under certain circumstances with more favorable treatment of that group under other circumstances).
} 
(b) two years after an investor ... ceases to pursue claims or proceedings before a tribunal or court under the law of a Party, or when such proceedings have otherwise ended and, in any event, no later than 10 years after the date on which the investor ... first acquired or should have first acquired knowledge of the alleged breach and knowledge that the investor has incurred loss or damage thereby.

In accordance with Section 93 of the Act on the Federal Constitutional Court, the limitation periods for a constitutional complaint are much shorter. For instance, pursuant to paragraph 3 thereof, a constitutional complaint against a law "may only be lodged within one year of the law entering into force ...."

\section{E. Justifiability of Differential Treatment}

We found above that nationals are not without effective judicial protection in Germany. Should the Federal Constitutional Court, on the contrary, conclude that the protection provided by German law is not equivalent to the remedies available under the CETA and, as a consequence, find that nationals are disadvantaged (for example, because of the way damages are being assessed or because of different limitation periods), the CETA investment dispute resolution mechanism might still be justifiable. Equality before the law is not an absolute principle. ${ }^{197}$ It is settled case law of the Federal Constitutional Court that Article 3.1 of the Basic Law:

[D]oes not prohibit the legislature from all differentiation. But the legislature violates the fundamental right if in provisions that relate to groups of people it treats one group of persons addressed differently from other persons addressed although there are no differences between the two groups of such a nature and weight that they could justify the unequal treatment .... 198

A stricter test applies when the differential treatment relates to personal characteristics that cannot be changed easily, along the lines of those mentioned in paragraph 3 of Article 3 of the Basic Law, such as homeland and origin. ${ }^{199}$ The same is true in cases in which the principle of equality of arms is concerned. ${ }^{200}$ In the current instance, the ground of differential treatment is the nationality of the investor.

It is worth recalling here that, under the CETA, holding shares in a company of the other Party would satisfy the definition of "investment" in Article 8.1. Thus, a foreign nationality can be constructed in conformity with the CETA. All things considered, we can summarize that the principle of equality before the law does not preclude lawmakers from treating different groups of investors differently, provided that such differential treatment can be justified by "sufficiently weighty reasons." 201

\footnotetext{
${ }^{197}$ Contra Pietzcker, supra note 29 , at para. 39.

${ }^{198}$ Bundesverfassungsgericht [BVerfG] [Federal Constitutional Court], 1 BvR 284/96, Mar. 14, 2000, para. 41 (reference omitted).

${ }^{199}$ Bundesverfassungsgericht [BVerfG] [Federal Constitutional Court], 1 BvL 13/11, June 23, 2015, para. 71; Bundesverfassungsgericht [BVerfG] [Federal Constitutional Court], 1 BvR 166/93, June 20, 1995, para. 38.

${ }^{200}$ Pietzcker, supra note 29, paras. $58,65$.

${ }^{201}$ Bundesverfassungsgericht [BVerfG] [Federal Constitutional Court], 1 BvL 21/11, Jan. 24, 2012, para. 44; Bundesverfassungsgericht [BVerfG] [Federal Constitutional Court], 2 BvL 4/09, Jan. 17, 2012, para. 66; Bundesverfassungsgericht [BVerfG] [Federal Constitutional Court], 1 BvR 611/07, Jul. 21, 2010, para. 84.
} 


\section{Rationale for ISDS}

\section{Rule of Law Rationale and Access to Justice}

The ISDS system, as it exists, was created because national court systems were not deemed adequate by foreign investors. The system addresses, in other words, deficiencies in the administration of justice by national authorities. ${ }^{202}$ Reportedly, problems of partiality and inefficiency do not only prevail in developing countries, especially in politically highly sensitive cases. ${ }^{203}$ Fear of bias led to the establishment of the Chapter 19 mechanism in the North American Free Trade Agreement ("NAFTA"). ${ }^{204}$ Domestic courts apply, and are bound by, ever changing domestic law and therefore cannot remedy any implementation deficits of domestic law, ${ }^{205}$ unless, of course, international law takes precedence over domestic law in the national legal order, such as in the Netherlands ${ }^{206}$ - something that is the absolute exception among the constitutional orders of the world. ${ }^{207}$ As mentioned above, with regard to the CETA, direct effect has been explicitly foreclosed. In the case of China, for instance, foreign investors can no longer take legal action against the Chinese government before domestic courts because a provision to that effect in Chinese administrative procedural $\operatorname{law}^{208}$ was repealed. ${ }^{209}$ On top of that, a national treatment obligation in an international investment agreement would not ordinarily capture procedural aspects. For example, the national treatment obligation in Article 8.6.1 of the CETA is confined to "the establishment, acquisition, expansion, conduct, operation, management, maintenance, use, enjoyment and sale or disposal" of investments.

So all that foreign investors are left with is domestic law, which may be at odds with the investment obligations of the host state, or ISDS. ${ }^{210}$ The Advocate General in Opinion 1/17 acknowledged that: "[T]hat possibility [of being able to bring matters before the CETA Tribunal] merely compensates for the fact that the CETA cannot be relied on directly before the domestic courts

\footnotetext{
${ }^{202}$ David Collins, An Introduction to International Investment LaW 214 (2017); Stephan W. Schill, Authority, Legitimacy, and Fragmentation in the (Envisaged) Dispute Settlement Disciplines in Mega-Regionals, in MEGA-REGIONAL Trade Agreements: CETA, TTIP, and TiSA: New Orientations for EU External Economic Relations 132 (Stefan Griller et al. eds., 2017); Jörn Griebel, Internationales Investitionsrecht 24-25 (2008); Puig \& Shaffer, supra note 108 , at $369,390$.

${ }^{203}$ Bronckers, supra note 11, at 671, 673, 676; Christian Tietje and Freya Baetens, The Impact of Investor-State-Dispute Settlement (ISDS) in the Transatlantic Trade and Investment Partnership (Study prepared for Minister for Foreign Trade and Development Cooperation, Ministry of Foreign Affairs, The Netherlands, June 24, 2014), para. 135, https://www. rijksoverheid.nl/documenten/rapporten/2014/06/24/the-impact-of-investor-state-dispute-settlement-isds-in-the-ttip. See also Judicial Independence, The Global Competitiveness Report 2018, WORLD ECONOMIC FORUM (2020), http://reports.weforum. org/global-competitiveness-report-2018/competitiveness-rankings/\#series=EOSQ144.

${ }^{204}$ North American Free Trade Agreement, Dec. 17, 1992, 32 ILM 289. See Czarina Powell, The NAFTA Alternative: Saving KORUS FTA Dumping Appeals from the Dumps, 39 CAN.-U.S. L.J. 36, 53-54 (2015); Michael S. Valihora, NAFTA Chapter 19 or the WTO's Dispute Settlement Body: A Hobson's Choice for Canada, 30 CASE W. RES. J. INT'L L. 447, 452 (1998).

${ }^{205}$ Dolzer \& Schreuer, supra note 51, at 235; Christian Riffel, Regulatory Safeguards in Mega-Regionals Against Sovereignty Loss, 20 MAX Planck Y.B.U.N.L. 322, 329 (2016); Quick, supra note 178, at 285-86. See also European Commission, Investment in TTIP and Beyond - The Path for Reform: Enhancing the Right to Regulate and Moving from Current Ad Hoc Arbitration Towards an Investment Court, 9 (May 5, 2015), http://trade.ec.europa.eu/doclib/docs/2015/may/tradoc_ 153408.PDF.

${ }^{206}$ Grondwet voor het Koninkrijk der Nederlanden [Gw] [Constitution of the Kingdom of the Netherlands] art. 94, available at https://www.government.nl/documents/regulations/2012/10/18/the-constitution-of-the-kingdom-of-the-netherlands2008 ("Statutory regulations in force within the Kingdom shall not be applicable if such application is in conflict with provisions of treaties or of resolutions by international institutions that are binding on all persons.").

${ }^{207}$ See Bronckers, supra note 11, at 665, 674.

${ }^{208}$ Administrative Procedure Law of the People's Republic of China art. 72 (promulgated by Order No. 16 of the President of the People's Republic of China, Apr. 4, 1989, effective Oct. 1, 1990).

${ }^{209}$ Decision of the Standing Committee of the National People's Congress Amending the Administrative Procedure Law of the People's Republic of China (Nov. 1, 2014, effective May 1, 2015). See also Tao Li \& Zuoli Jiang, Human Rights, Justice, and Courts in IEL: A Critical Examination of Petersmann's Constitutionalization Theory, 21 J. INT'L ECON. L. 193, 207 (2018).

${ }^{210}$ On the limitations of state-to-state dispute settlement, see Bronckers, supra note 11, at 659-60.
} 
and tribunals of the Parties." ${ }^{211}$ In situations where domestic accountability is wanting, ISDS steps in to hold local rulers accountable and thus upholds the rule of law in lieu of the domestic judicature- the international concept of the rule of law that is. ${ }^{212}$ One might raise the question as to whether political risk insurance would serve the same purpose. ${ }^{213}$ But then again, one could propagate the same-away from judicial protection and toward relief through insurance-in relation to many other types of disputes. Beyond that, ISDS is not infrequently used by foreign investors as a leverage to make governments negotiate an out-of-court settlement. ${ }^{214}$

Even when fully independent, Gundel contends that national judges, adjudicating in the context of state liability on the use of taxpayers' money for the benefit of foreign investors, are both adjudicators and party members, as is apparent from Article 4(1) of the Articles on State Responsibility: $^{215}$ "The conduct of any State organ shall be considered an act of that State under international law, whether the organ exercises legislative, executive, judicial or any other functions ..."216

According to the United States Trade Representative, ISDS may be particularly advantageous to small and medium-sized enterprises because they "often lack the resources or expertise to navigate foreign legal systems." ${ }^{217}$ On that note, the CETA accommodates the interests of small and medium-sized enterprises by reducing their financial burden in different ways, such as by the possibility of holding consultations through videoconference ${ }^{218}$ or having the case heard by a sole Member of the Tribunal. ${ }^{219}$ Furthermore, the European Commission envisages "the provision of technical assistance" for small and medium-sized enterprises. ${ }^{220}$

\section{Increase of FDI and Depoliticization of Investment Disputes}

Whether investment protection actually increases the amount of foreign direct investment ("FDI") that a particular host state receives is difficult to determine empirically because it hinges on a counterfactual: Would the foreign investor have made the investment even without the legal protection derived from international investment agreements? ${ }^{221}$ Some might, but others might not, depending on their risk-averseness and, in particular, on the role that legal risks - concomitant with investing in another jurisdiction-take in their overall risk assessment. ${ }^{222}$

Lowe maintains that international investment agreements "reassure actual and potential investors .... In the absence of such confidence, investors are likely to take their investments

\footnotetext{
${ }^{211}$ Opinion of Advocate General Bot, supra note 73, at para. 205. See also, CETA Opinion, supra note 6, at para. 181.

${ }^{212}$ Broches, supra note 19, at 163; Chase, supra note 19, at 218; Schill \& Djanic, supra note 123, at 31-32, 34, 36-39; Puig \& Shaffer, supra note 108, at 375-79. Contra JOHN, supra note 11, at 253. For the historical development of ISDS, see ALEC Stone Sweet \& Florian Grisel, The Evolution of International Arbitration: Judicialization, Governance, LEGITIMACY 66-78 (2017).

${ }^{213}$ Puig \& Shaffer, supra note 108 , at $385-87$.

${ }^{214}$ Dolzer \& Schreuer, supra note 51 , at 237.

${ }^{215}$ Gundel, supra note 82 , at 127.

${ }^{216}$ GA Res. 56/83, Articles on Responsibility of States for Internationally Wrongful Acts (Dec. 12, 2001) (corrected by A/56/ 49(Vol. I)/Corr.4) (emphasis added).

${ }^{217}$ ISDS: Important Questions and Answers, UNITED STATES TRADE REPRESENTATIVE (Mar. 2015), https://ustr.gov/ABOUTUS/POLICY-OFFICES/PRESS-OFFICE/BLOG/2015/MARCH/ISDS-IMPORTANT-QUESTIONS-AND-ANSWERS-0.

${ }^{218}$ CETA art. 8.19.3.

${ }^{219}$ CETA arts. 8.23.5, 8.27.9.

${ }^{220}$ Statement by the Commission and the Council on Investment Protection and the Investment Court System, 2017 O.J. (L 11) 21.

${ }^{221}$ Dolzer \& Schreuer, supra note 51, at 23; Schill \& Djanic, supra note 123, at 31, 38.

${ }^{222}$ See Dolzer \& Schreuer, supra note 51, at 21, 23; Collins, supra note 202, at 217; Jacob \& Schill, supra note 178, paras. 143, 148, 157. See also Saluka Investments v. Czech Republic, UNCITRAL, Partial Award, para. 301 (Mar. 17, 2006) ("An investor's decision to make an investment is based on an assessment of the state of the law and the totality of the business environment at the time of the investment ....").
} 
elsewhere." 223 Against this, Sornarajah points out that "[t]he correlation between the treaties could not be established in clear terms." 224 According to Berger and others, the impact of investment protection on FDI is very much contingent upon the content of the respective agreement. ${ }^{225}$ They concluded that national treatment provisions are more significant than ISDS.

The prevalence of nationality construction might give some indication that international legal protection is a consideration that matters to foreign investors. That said, in 2017, Brazil was the world's fourth top recipient of FDI, with only one BIT in force (with Angola). ${ }^{226}$ As for Australia, the Productivity Commission found that "[a]n examination of foreign investment trends with Australia's main foreign investment partners suggests that ISDS provisions are unlikely to have been relevant considerations in the investment decisions of Australian firms investing abroad or foreign firms investing in Australia." 227 Still, the European Commission asserts that "[i]nternational investment rules and international investment dispute settlement have a role to play in encouraging and retaining investment."228 By allowing foreign investors to sue European governments, the Commission hopes to attract and retain FDI, which is "vital for ensuring economic growth and jobs in the EU." 229 That is a public choice. The rub is this: Should a constitutional court show deference to that choice?

Additionally, whether ISDS also helps depoliticize investment disputes-because it forecloses diplomatic protection ${ }^{230}$ - has recently been put into question, ${ }^{231}$ especially when the home state of the investor and the host state have the authority under the treaty to issue binding interpretations, thereby interfering with ongoing disputes. ${ }^{232}$ Schreuer submits that "[i]nvestor-State arbitration serves not only the investor's interests but has an important function in the public interest

\footnotetext{
${ }^{223}$ Lowe, supra note 13 , at 433 .

${ }^{224}$ Muthucumaraswamy Sornarajah, Resistance and CHANGE IN THE INTERNATIONAL LAW ON Foreign INVESTMENT 403 (2015).

${ }^{225}$ Axel Berger et al., Do Trade and Investment Agreements Lead To More FDI? Accounting for Key Provisions Inside the Black Box, 10 INT'L ECON. \& ECON. POL'Y 247, 268-70 (2013).

${ }^{226}$ UNCTAD, World Investment Report 2018: Investment and New Industrial Policies, 4 (2018). But see Paulo Cavallo, Brazil, BITs and FDI: A Synthetic Control Approach, 20 J. World InV. \& Trade 68, 95-96 (2019) (arguing that the inflow of FDI would have been even greater in the presence of BITs).

${ }^{227}$ Trade \& Assistance Review 2013-14, Productivity Commission, at 80 (Annual Report Series, 2015), https://www.pc. gov.au/research/ongoing/trade-assistance/2013-14/trade-assistance-review-2013-14.pdf.

${ }^{228}$ The Multilateral Investment Court Project, European Commission (Oct. 10, 2018), http://trade.ec.europa.eu/doclib/ press/index.cfm?id=1608.

${ }^{229} \mathrm{Id}$.

${ }^{230} \mathrm{Cf}$. ICSID Convention art. 27(1); UNCITRAL Rules on Transparency in Treaty-based Investor-State Arbitration art. 5(2).

${ }^{231}$ Geoffrey Gertz et al., Legalization, Diplomacy, and Development: Do Investment Treaties De-Politicize Investment Disputes?, 107 World Dev. 239, 248 (2018); Catharine Titi, Are Investment Tribunals Adjudicating Political Disputes?, 32 J. INT'L ARB. 261, 262-65, 278, 281-85, 287-88 (2015); Martins Paparinskis, Limits of Depoliticisation in Contemporary Investor-State Arbitration, in Select Proceedings of the European Society of International LaW, Vol. 3, 273-75, 282 (James Crawford \& Sarah Nouwen eds., 2010). Contra Ursula Kriebaum, Evaluating Social Benefits and Costs of Investment Treaties: Depoliticization of Investment Disputes, 33 ICSID REv. 14, 19, 23, 26-28 (2018) (arguing that ISDS provides for a neutral forum); Gundel, supra note 82, at 127 (same); Chase, supra note 19, at 221 (same); Jan Paulsson, The Pyramids Case, in Collected Courses of the International Academy for Arbitration LaW, Year 2012, vol. 1, 19 (2014) (same); Anna De Luca \& Giorgio Sacerdoti, Investment Dispute Settlement, in RESEARCH HANDBOOK ON Foreign Direct Investment 194, 198 (Markus Krajewski \& Rhea Tamara Hoffmann eds., 2019) (same); Kenneth J. Vandevelde, A Brief History of International Investment Agreements, 12 U.C. DAVIS J. INT'L L. \& POL'Y 157, 175 (2005) (same). See also Banro American Resources v. Democratic Republic of the Congo, ICSID Case No. ARB/98/7, Award, para. 15 (Sept. 1, 2000) ("One of the main objectives of the mechanisms instituted by the Washington Convention was to put an end to international tension and crises, leading sometimes to the use of force, generated in the past by the diplomatic protection accorded to an investor by the State of which it was a national .... The Washington Convention introduced mechanisms ... which avoid political confrontation between the host State and the State of which the investor is a national.").

${ }^{232}$ See, e.g., Free Trade Agreement Between the Government of Australia and the Government of the People's Republic of China, June, 6, 2015, arts. 9.18.2, 3; Agreement Between Japan and the United Mexican States for the Strengthening of the Economic Partnership, Sept. 17, 2004, arts. 84(2), 89.
} 
for the relations between the States concerned." ${ }^{233}$ Even more so, diplomatic protection would not be viable considering the scale of FDI in the twenty-first century.

\section{Reciprocity: The Decision of the French Constitutional Council on CETA}

When a national legal order does not put foreigners at a disadvantage, ISDS may not be necessary. But that alone does not make it discriminatory against nationals because it could be justified on the basis that it protects national proprietary interests abroad by means of an international investment tribunal. On reciprocity grounds, the same kind of protection would have to be accorded to foreigners in the host jurisdiction.

That, in a nutshell, was the line of reasoning of the French Constitutional Council regarding the issue of whether the CETA investment dispute resolution mechanism conflicts with the principle of equality before the law under the French constitution. ${ }^{234}$ The Constitutional Council held that, as long as foreign investors from all contracting parties have access to the investment tribunal, on a reciprocal basis, no infringement can be found. ${ }^{235}$ The Council, consequently, equated reciprocity with equal treatment. In deciding the case, the Council relied on Point 6(a) of the CETA Joint Interpretative Instrument mentioned above. The second sentence thereof is worth recalling: "CETA will not result in foreign investors being treated more favourably than domestic investors." This may be true in substantive terms but not necessarily in procedural terms, given that, due to its nature, the Joint Interpretative Instrument cannot diminish express treaty rights, such as the right to bring a claim.

The difference in treatment is, according to the Constitutional Council, justified by the overriding general interest in "creating a protective framework for French investors in Canada and ... attracting Canadian investors in France." ${ }^{236}$ The latter argument was also advanced by the Advocate General in Opinion 1/17. ${ }^{237}$ The situation at hand is comparable to the government offering a lower tax rate to attract businesses from overseas, justified by the prospective jobs and tax revenue that otherwise would not eventuate. Of note, the Constitutional Council compared "Canadian investors and other foreign investors in France." ${ }^{338}$ This latter point does not hold water as the issue concerns reverse discrimination, not most-favored-nation treatment.

\section{Sufficiently Weighty Reason}

Having discussed the rationale for investor-state adjudication in general, the pertinent question is whether the CETA mechanism could be justified by overriding reasons of public interest, as opined by the French Constitutional Council and Advocate General Bot. The consideration of allowing Germans that hold investments in Canada to make use of the investment court system might sway the Court. There is no denying that investment arbitration provides a country's overseas investments with effective legal protection-this is why it is controversial in the first place. If one believes that foreign investors need international law protection, ${ }^{239}$ then that notion encompasses an effective dispute settlement and enforcement mechanism, in keeping with ubi ius ibi remedium.

At this juncture, a word on the protection provided by Canadian law is in order. It is well-known that Canadian constitutional law does not protect property rights. ${ }^{240}$ Nor does the

\footnotetext{
${ }^{233}$ Christoph Schreuer, Investment Protection and International Relations, in THE LAW OF InTERnATIONAL ReLATIONS: Liber Amicorum Hanspeter Neuhold 357 (August Reinisch \& Ursula Kriebaum eds., 2007).

${ }^{234}$ For a case summary, see Larik, supra note 59.

${ }^{235}$ Constitutional Council decision on CETA, supra note 12, at paras. $38,40$.

${ }^{236} \mathrm{Id}$. at para. 38 .

${ }^{237}$ Opinion of Advocate General Bot, supra note 73, at paras. 209, 212.

${ }^{238}$ Constitutional Council decision on CETA, supra note 12, at para. 38.

${ }^{239}$ Alvarez, supra note 179 , at 567-68.

${ }^{240} \mathrm{Cf}$. Canadian Charter of Rights and Freedoms, Part I of the Constitution Act, 1982, available at http://laws-lois.justice.gc. ca/eng/Const/page-15.html.
} 
Investment Canada Act of 1985 provide for substantive investment protection. ${ }^{241}$ Then again, common and statutory law in Canada do. ${ }^{242}$ Furthermore, Section 15 of the Canadian Charter of Rights and Freedoms on equality rights, including non-discrimination, only applies to individuals, not to corporations. ${ }^{243}$ It is an open question if the German constitutional court would find that level of property protection sufficient, especially in light of the cases that Canada lost under NAFTA. ${ }^{244}$ A recent study by de Mestral and Morgan examined the issue of "whether disputes submitted by foreign investors against Canada under Chapter 11 [NAFTA] could have been brought under Canadian law" and found that "in the great majority of cases there is no domestic remedy equivalent to one sought under Chapter 11." ${ }^{245}$ For "Canadian law does not generally provide foreign investors with remedies equivalent to those provided for under Chapter 11."246 In sum, "there exists considerable disparity between Canadian law and the remedies available under NAFTA Chapter 11, as well as within other foreign investment protection agreements." 247 In which jurisdiction individual remedies from an international forum are desirable is perforce a political decision to be made by the competent authorities who dispose of the relevant information. With regard to Canada, the European Commission and several Member States pointed out that its law "does not necessarily offer adequate protection to European investors in relation to discrimination or expropriation." 248

\section{F. Conclusions}

Article 3(1) of the Basic Law accords an ample margin of appreciation to the German legislature. ${ }^{249}$ When the government seeks to improve the legal situation of a particular group of nationals abroad, the principle of equality before the law does not impede that improvement, as long as no nationals are precluded a priori from meeting the requirements necessary to benefit from international law protection-here investing abroad. As emphasized by the French Constitutional Council, foreign investors from all parties have access to the CETA Tribunal as a matter of principle. The different treatment of national investors bears a reasonable relationship to the rational policy of providing German investors in Canada with international legal protection on a reciprocal basis. Depending on the national legal order, investor-state adjudication may not even be discriminatory in cases in which domestic law provides national investors with equivalent legal protection. In this author's view, this is true of Germany because of the stronger legal position enjoyed by nationals under German law. The principle of equality before the law, as enshrined in Article 3(1) of the Basic Law, does not ensure equal access of nationals to international courts and tribunals; rather, it guarantees equal access to national courts.

\footnotetext{
${ }^{241}$ Legal text available at https://laws-lois.justice.gc.ca/eng/acts/I-21.8/index.html.

${ }^{242}$ Canadian Bill of Rights $\$ 1($ a). See also J. Anthony VanDuzer, Canada, in The Legal Protection of Foreign InVESTMENT: A Comparative Study 195 (Wenhua Shan ed., 2012).

${ }^{243}$ Armand de Mestral \& Robin Morgan, Does Canadian Law Provide Remedies Equivalent to NAFTA Chapter 11 Arbitration?, in Second Thoughts: Investor-State Arbitration between Developed Democracies 178 (Armand de Mestral ed., 2017).

${ }^{244}$ For all the NAFTA cases against Canada, see Cases filed against the Government of Canada, GLOBAL AFFAIRS CANADA (Jan. 29, 2019), http://www.international.gc.ca/trade-agreements-accords-commerciaux/topics-domaines/disp-diff/gov.aspx? lang=eng.

${ }^{245} \mathrm{de}$ Mestral \& Morgan, supra note 243, at 155-56, 178.

${ }^{246} I d$. at 178 .

${ }^{247} I d$. at 180 .

${ }^{248}$ Opinion of Advocate General Bot, supra note 73, at fn. 78.

${ }^{249}$ Bundesverfassungsgericht [BVerfG] [Federal Constitutional Court], 1 BvL 3/05, Nov. 11, 2008, para. 62; Bundesverfassungsgericht [BVerfG] [Federal Constitutional Court], 2 BvL 5/00, June 8, 2004, para. 73; Bundesverfassungsgericht [BVerfG] [Federal Constitutional Court], 1 BvR 166/93, June 20, 1995, para. 38. For the same argument with regard to the European Union's external action, see Opinion of Advocate General Bot, supra note 73, at paras. 211-12.
} 
Passing the constitutional hurdle set by the principle of equality before the law does not mean that the CETA investment court system will be found compatible with the German constitution. The claim of discrimination is only one of the claims directed against investor-state dispute resolution. In Opinion 1/17, the ECJ found the CETA Tribunals compatible with EU primary law, in particular with the principle of autonomy as laid down in Articles 267 and 344 of the TFEU. ${ }^{250}$ This occurred against the background that, in the past, the Court had rejected the jurisdiction of other courts, such as the European Court of Human Rights and the Unified Patent Court, over matters relating to European Union law. ${ }^{251}$ As a final point, it should be noted that if the investment court system fell through because of an adverse ruling of the Federal Constitutional Court, then we would be left with the existing ISDS system and all its failings. ${ }^{252}$ The existing system would not be directly affected by an adverse ruling. So, whatever the outcome, ISDS is here to stay-in which form, whether institutionalized or not, remains to be seen.

\footnotetext{
${ }^{250}$ CETA Opinion, supra note 6 , at paras. 161, 245.

${ }^{251}$ Opinion $2 / 13$, supra note 87 , at para. 258; Opinion $1 / 09$, supra note 87 , at para. 89.

${ }^{252}$ See, e.g., George Kahale III, ISDS: The Wild, Wild West of International Law and Arbitration, 44 Brook. J. INT'L L. 1 (2018); David Gaukrodger, Who Chooses the Judges (And Should They)?, OECD ON THE Level (Apr. 20, 2018), https:// oecdonthelevel.com/2018/04/20/who-chooses-the-judges-and-should-they/.
}

Cite this article: Riffel C (2020). Does Investor-State Dispute Settlement Discriminate Against Nationals?. German Law Journal 21, 197-222. https://doi.org/10.1017/glj.2020.10 